\title{
O Controle Externo na América Latina
}

(Versão preliminar para discussão interna)

\author{
Marcus André Melo
}

INSTITUTO FERNANDO HENRIQUE CARDOSO

Maio 2007 


\section{Introdução}

A questão do controle e responsabilização sobre as atividades dos governos tem adquirido crescente centralidade na agenda de reformas na América Latina, refletindo uma tendência em escala global de busca do fortalecimento dos mecanismos de accountability democrática. Não obstante, há que se reconhecer que este novo foco permite que se re-atualize um desafio central da democracia representativa que tem estado presente desde sua emergência no século XVIII. Pelo menos desde Montesquieu e os Federalistas, a questão tem sido revisitada em suas bases conceituais e inúmeras propostas de fortalecimento dos mecanismos de controle têm sido apresentadas. A problematizarão contemporânea da questão tem sido influenciada fortemente pelo chamado neo-institucionalismo econômico que tem iluminado suas complexas implicações sobre o comportamento fiscal de governos e desenvolvimento econômico no longo prazo. $\mathrm{O}$ controle externo tem sido visto como peça central da qualidade institucional de um país. e o ambiente institucional é fundamental para a consecução de objetivos econômicos, fiscais e sociais.

Historicamente a América Latina tem se caracterizado pela debilidade de suas instituições de hecks and balances - ou de accountability horizontal como O' Donnell (1998) as denominou. Os débeis controles exercidos pelo Legislativo e Judiciário refletem um padrão histórico caracterizado pelo autoritarismo e governos militares na região. A transição para a democracia nas últimas duas décadas tem sido acompanhada por intenso reformismo institucional que se estendeu amplamente para a área do controle externo. Por outro lado, a retomada pelos Legislativos da região do poder de aprovar, emendar e fiscalizar o gasto público também levou a uma redefinição do papel passivo do Legislativo durante os governos autoritários.

Este position paper apresenta um mapeamento das principais questões da agenda de pesquisas sobre a questão do controle externo, ao mesmo tempo que apresenta um diagnóstico sumário da situação das instituições de controle na América Latina. O foco empírico deste diagnóstico sumário é bastante seletivo, e voltado para os casos de Brasil, Chile e Argentina. Estes três países exemplificam modelos e padrões de controle bastante distintos ao mesmo tempo em que correspondem a experiências contrastantes de reforma institucional setorial. Adotando o modelo de Tribunal de Contas, o Brasil representa uma experiência marcada pelo incrementalismo e progressivo aperfeiçoamento institucional e sinaliza os problemas resultantes da ausência de poder jurisdicional na agência de controle. A Argentina representa o 
caso simétrico. Objeto de uma reforma radical, de mudança de modelo de Tribunal de Contas para Audit Board, o controle externo reflete as vicissitudes da mudança institucional com propósitos particularistas em um ambiente institucional volátil, polarizado e de baixos incentivos a cooperação. O Chile, por sua vez, representa um terceiro modelo - o de Auditor Geral (com alguns traços inusitados) - em uma experiência relativamente bem sucedida desde sua criação na década de 20.

A primeira seção deste paper discute o debate recente sobre a questão do controle e dos hecks and balances. Duas visões contrastantes da questão são discutidas. A primeira vê a questão da debilidade institucional do controle na América Latina como resultando da concentração histórica do poder no executivo, enquanto a segunda sustenta que ela é fundamentalmente causada pela inefetividade da accountability vertical entre cidadãos e governos. A segunda seção apresenta um panorama sobre os modelos de instituição superior de controle (doravante ISCs) a partir da experiência internacional. O objetivo é apresentar as características principais dos três modelos institucionais e discutir os requisitos mais amplos para o seu funcionamento. A terceira se centra na América Latina, apresentando-se um quadro geral das ISCs na região, além de três estudos de caso sumários sobre as ISC do Brasil, Argentina e Chile.

\section{O controle e a responsabilização de governantes: questões conceituais básicas}

$\mathrm{Na}$ linguagem consagrada de $\mathrm{O}^{\prime}$ Donnell, as instituições de controle externo são instituaiones de balance e representam mecanismos de accountability horizontal. Elas se distinguem do mecanismo de accountability vertical pelo fato de que nesse último o controle dos governantes é feito diretamente através das eleições entre cidadãos e seus representantes. Para aquele autor na accountability horizontal a sanção ao comportamento desviante de governantes ocorre entre instituições ou agentes públicos: o Legislativo, as instituições Judiciais e parajudiciais (Ministério Público, Tribunal de Contas, Ombudsman, dentre outros).

$\mathrm{Na}$ linguagem do novo institucionalismo econômico, a relação entre cidadãos e governantes assume a forma de uma relação principal-agente. Os cidadãos enquanto principais premiam ou sancionam o desempenho dos governantes enquanto agentes de um ato de delegação representado pelas eleições. No papel de agentes s eleitores utilizam o voto retrospectivo - ou seja exercem o voto orientado para o desempenho dos candidatos, mas podem também exercer o voto prospectivo, orientado para as promessas implícitas nesta 
delegação. Os contratos entre cidadãos-principais e governante-agentes são contratos “incompletos" - isto é deixam em aberto um número elevado de "cláusulas" não especificadas - dando margem ao comportamento oportunista dos agentes-políticos. Este podem não honrar promessas de campanha ou falsear suas preferências em promessas que nunca tiveram a intenção de cumprir.

$\mathrm{Na}$ base destas distorções está o problema da assimetria de informação entre principais e agentes a qual gera duas classes de problemas. Numa situação caracterizada pelo chamado moral hazard (risco moral), o agente pode ter incentivos para se desviar das preferências do principal por não ter informação completa sobre o comportamento do agente: os custos de monitoramento são altos e muitos atos e decisões não são diretamente observáveis pelo agente. O principal também pode se deparar com o problema de adverse selection (seleção adversa). Devido à sua incapacidade de distinguir bons e maus governantes - a verdadeira natureza e compromisso público de um agente público é uma informação privada sobre a qual apenas o agente dispõe de informação completa. Como o exercício de mandatos eletivos gera benefícios tangíveis, o processo de seleção de agentes - as eleições - tende a atrair um número desproporcional de candidatos cujas promessas são falseadas.

Estas duas classes de falha do mercado político têm sua origem nos problemas de assimetria de informação e são enfrentadas pelos eleitores que buscam estratégias para minimizá-las. A reputação de agentes públicos, informação sobre seu comportamento no passado, entre outras estratégias, permite uma redução dos seus efeitos. Salvo nas situações tipificadas como comportamento criminoso, e nos reduzidos casos de recall de mandatos, a sanção pelos cidadãos nas democracias representativas em relação ao desempenho dos governantes tem lugar apenas em cada eleição periódica.

O controle sobre os atos dos governantes envolve uma dimensão dúplice: de um lado a sanção ao eventual comportamento desviante; de outro, o juízo quanto ao seu desempenho enquanto gestor público. Os hecks and balances entre os poderes Executivo, Judiciário e Legislativo cumpre papel relevante nestas duas dimensões. Parte da literatura entende que a relação entre os poderes é uma relação de accountability, e que a qualidade desta relação é determinada pela cultura, pela história e por processos sociais mais amplos. A transição para uma sociedade com mecanismos mais robustos de accountability horizontal mais é parte de um processo de transformação cultural mais amplo. Nesta vertente interpretativa, accountability é entendida em um sentido "fraco" do conceito. A relação exercida por um ombusdman, que 
não implica em sanção efetiva do agente do comportamento desviante, seria entendida como relação de accountability.

Outra parte da literatura destaca o papel das instituições políticas e da estrutura de incentivos resultante como determinantes na relação de accountability (Moreno, Crisp e Shugart 2003). Esta relação é entendida em sentido "forte" como necessariamente envolvendo capacidade de sanção pelo agente. Estes autores argumentam que a eficiência do controle é determinada fundamentalmente pela qualidade da cadeia de delegação entre cidadãos, como mandatários ou "principais", e políticos, como seus agentes. Ancorados nesse tipo de modelo, eles afirmam que a accountability é sobretudo um ato de delegação. Os incentivos para tornar os agentes políticos responsabilizáveis pelos seus atos e para punir desvios são moldados pela cadeia de delegação, que assume formas distintas segundo a natureza do regime (presidencialismo, parlamentarismo). Como os chefes dos executivos nomeiam os membros do judiciário e de outras instituições similares, como ombusdman, procuradores gerais, entre outros, que devem ser ratificados pelo Legislativo, os cidadãos, como eleitores, estão envolvidos indiretamente na cadeia de delegação.

Em sistemas presidencialistas com separação de poderes, a cadeia da delegação até o Executivo é direta em virtude da independência entre a origem do mandato e a sobrevivência política do Executivo e do Legislativo (ou seja a investidura ou retirada do poder obedecem a lógicas distintas e autônomas). Dessa forma, o eleitorado tem dois agentes (três se o congresso é bi-cameral) que transacionam entre si. Pelo fato de os checks and balances serem essencialmente uma relação entre iguais, os autores concluem que não há delegação envolvida na relação entre esses dois agentes. Ademais, essa relação - denominada troca horizontal (horizontal exchange) e não responsabilização horizontal (horizontal accountability) - não envolve sanções, a não ser no raro caso de impedimento de executivos pelo Legislativo. É por isso que rejeitam o conceito de responsabilização horizontal como um oxymoron (Idem, p. 80).

A questão de fundo, portanto, para Moreno, Crisp e Shugart é que a responsabilização horizontal é função da qualidade da responsabilização vertical entre eleitores e seus representantes. Se essa relação vertical é deficiente, então a horizontal será necessariamente afetada. Das patologias criadas pelas distintas configurações de regras eleitorais e sistemas partidários, esse autores deduzem as insuficiências potenciais do que denominam troca horizontal. Sistemas centrados nos candidatos, como os com regras eleitorais que incentivam a competição intrapartidária entre candidatos (Brasil, Equador), enfraquecem essa conexão 
porque os representantes tenderão a beneficiar os interesses específicos de suas bases em detrimento de questões programáticas de maior alcance. Da mesma forma - e no pólo oposto -, sistemas muito centralizados, em que a seleção de candidatos está monopolizada nas mãos de líderes partidários, os representantes serão responsivos às preferências daqueles, e não às dos eleitores (Venezuela, Argentina pré 90).

A natureza da troca horizontal entre os diferentes poderes e agências autônomas depende ainda de dois fatores adicionais. Esses atores institucionais devem ter poderes que se sobrepõem e são interdependentes (overlapping powers) (isto é, sua interação é necessária para a aprovação de leis ou para o exercício do governo) e devem estar ocupados por agentes com “ambição distintas e opostas", no sentido madisoniano. Se este não for o caso, quando, por exemplo, a maioria dos representantes está essencialmente interessada em patronagem e apropriação de rendas, não tendo, assim, incentivo para selecionar agentes públicos para as agências autônomas (inclusive os Tribunais de Contas e Judiciário) que possam exercer efetivamente controle sobre tais desvios, a troca horizontal degenera e se converte em conluio. Por outro lado, se os poderes não tiverem poderes sobrepostos, essa troca assume a forma de meros alarmes de incêndio e não de controle e sanção. A conclusão normativa mais geral dessa análise é que ceteris paribus os países que adotam a representação proporcional com voto preferencial ou com forte descolamento entre lideranças partidárias e eleitores apresentarão baixa capacidade de responsabilização. As instituições de controle não tem assim incentivos para exercer a atividade controle, tornando-se supérfluas

Nesta linha interpretativa a proliferação e fortalecimento de agência autônomas refletem as insuficiências dos mecanismos de accountability vertical. A deficiência estrutural do sistema representativo na América Latina e consequentemente a incapacidade dos eleitores de sancionarem e punirem governantes corruptos deve-se fundamentalmente à debilidade da relação entre eleitores e representantes. Sistemas partidários fragmentados e partidos débeis, clientelistas e não-programáticos produzem uma estrutura de incentivos perversa para o exercício do controle. A proliferação de agências de controle voltadas para o fortalecimento da responsabilização na América Latina assim expressa uma tentativa fadada ao fracasso de equacionar o déficit de controle sem equacionar o déficit nas relações verticais de accountability. A agenda positiva de fortalecimento da accountability passa nesta perspectiva pela reforma política e reforma institucional de forma ampla. $\mathrm{O}$ fortalecimento das relações verticais de 
accountability implicariam assim na redução dos problemas de moral hazard e adverse secletion no mercado político.

\section{A experiência internacional de controle externo: modelos de instituições de controle}

Não há um modelo institucional ideal de instituição superior de controle que possa ser discutido como parâmetro universal pelo fato de que há uma variabilidade nos desenhos institucionais que têm sido adotados com êxito em contextos e tradições históricas distintas. ${ }^{1}$ Pode-se identificar três modelos de atuação de ISCs no plano internacional que correspondem a três tipos distinto de desenho institucional (cf Tabela 1). Estes três modelos correspondem de Auditor Geral, o de Tribunal de Contas e os modelos colegiados com base em Audit Board. O modelo de ISC com Auditor Geral é aquele adotado nos países da ex-comunidade britânica das nações, além da Suécia, entre outros. Em um survey de 126 ISC de várias partes do mundo, esse modelo correspondia a 73 (57\%), enquanto os demais correspondiam a 17 (13\%), o restante $(30 \%)$ correspondendo a departamentos de auditoria ou estruturas administrativas similares. $^{2}$

A principal característica do modelo de Auditor Geral é a alta concentração de poder na figura do auditor geral (que acumula o cargo em muitos países com a de Comptroller). Neste modelo, a responsibilidade do controle é de natureza eminentemente individual, centrada na figura do Auditor Geral, e não institucional da ISC como um todo ou de quadro dirigente. $\mathrm{O}$ auditor detém, na maioria dos países, várias prerrogativas importantes tais como a liberdade ampla de recrutar pessoal para o serviço e de organizar os trabalhos de auditoria como bem lhe aprouver. Seu trabalho é realizado em estreita articulação com o Parlamento, através de um trabalho conjunto com as Comissões de Contas Públicas (Public accaunts Committees) (Stapenhurst 2004). A despeito da autonomia que desfruta, o auditor em muitos casos é estatutariamente funcionário do Legislativo.

O mandato do Auditor é em geral fixo, podendo ser estendido. $\mathrm{O}$ auditor geral não cumpre funções judiciais mas apenas prepara relatório e emite parecer sobre as contas públicas para apreciação do Parlamento. O foco do controle é, portanto, de natureza financeira e o perfil profissional é predominantemente caracterizado pela presença quase exclusiva de

2 INTOSAI (2001). Independence of Supreme Audit Institutions (SAIS) project. Final Task Force. 
auditores e contadores. Neste modelo a ação final do controle é exercida pelo Legislativo, a quem cabe deliberar sobre as recomendações e encaminhar eventuais sanções (comissões de inquérito, interpelações, dentre outras). O Executivo é obrigado por lei ou convenção a responder às objeções levantadas pelo Legislativo e suas Comissões. Como esse modelo de ISC é adotado, em geral, em países com regime parlamentarista de governo, a responsabilização implícita no exercício do controle externo está estreitamente associada ao próprio processo de formação de Gabinetes. ${ }^{3}$ Uma sanção legislativa sobre as contas públicas equivale a um voto de desconfiança podendo levar a queda do gabinete (com eventual mudança no portfolio ministerial), ou ainda à dissolução da Assembléia e convocação de eleições gerais.

Neste modelo o ciclo do controle é anual em função do papel exercido pelo Legislativo que delibera sobre todas as contas de um ano em bloco (em geral o ano anterior) (Figura 1). A celeridade do processo de auditagem torna-se um imperativo para a efetividade de todo o processo. Se por exemplo houver atraso na apresentação ou julgamento de contas rompe-se este ciclo, e o a efetividade do processo fica comprometida. Em comparação com o modelo de Tribunal de Contas, as contas no modelo de auditor geral são apresentadas em um nível menor de agregação, juntamente com o resultado das auditorias realizadas.

O modelo de Tribunal de Contas é adotado, dentre outros, em países com tradição de Public Law, como Portugal, Grécia e França. O modelo de Tribunais de Contas também é adotado na América Latina e na África Subsaariana. Angola, Cabo Verde, Guiné, GuinéBissau, São Tomé e Príncipe e Senegal utilizam tal modelo. A principal característica é que o Tribunal exerce controle jurisdicional, julgando as contas públicas e imputando responsabilização para irregularidades praticadas por agentes públicos. A estrutura organizacional está centrada em um colegiado de juízes, o qual é presidido por um dos seus membros. Como magistrados, estes últimos gozam de estabilidade garantida por lei. A estabilidade conferida aos juízes é maior do que aquela gozada pelos auditores no modelo anterior devido ao instituto da vitaliciedade - ou seu equivalente prático, o limite de idade aplicável no serviço público (Ver Figura 2).

3 Em muitos países há mecanismos de follow up pelos quais as comissões e a ISC estabelecem cronogramas de correção em relação as recomendações feitas Stapenhurst, Rick (2004) The Legislature and the Budget, The World Bank Institute. 


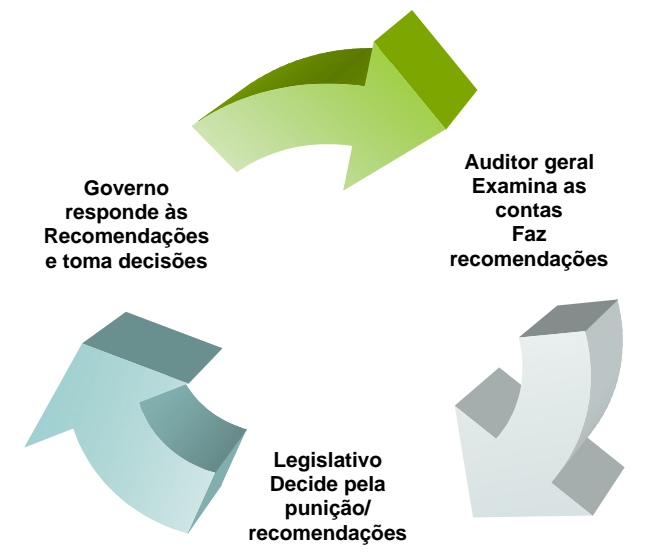

\section{Figura 1. O ciclo da accountability no modelo Auditor geral}

No caso do julgamento das contas do estado, o Tribunal elabora relatório e parecer prévio, em formato similar àquele cumprido pelo auditor geral. Este relatório e parecer prévio é geralmente apresentado em um nível maior de agregação do que no modelo anterior, e não contém as auditorias realizadas. No entanto, o Tribunal é corte judiciária em muitos paises como Portugal, Espanha e Grécia, mantendo forte independência frente ao Legislativo e Executivo. ${ }^{4}$ Assim, o Tribunal de Contas não julga o chefe do executivo quanto à análise de suas contas anuais. Quem faz o julgamento é o Poder Legislativo, através da Assembléia da Republica, seguindo ou não o parecer da ISC. Nos demais casos, em que são julgadas contas de agentes públicos individuais, o Tribunal funciona como órgão judicial de última instância. Não há portanto um Comitê Legislativo de Contas Públicas que aprecie os casos de gestores uma vez que essa atividade é exercida plenamente pelo Tribunal. O plano de atividades do Tribunal (auditorias etc) não é discutido com a comissão legislativa relevante, como no modelo anterior. O Tribunal pode imputar multas e declarar a inelegibilidade de gestores públicos ou a vedação do exercício de cargo público.

\footnotetext{
${ }^{4}$ Em países como o Brasil, a Alemanha e o Uruguai, o Tribunal de Contas cumpre o papel de tribunal administrativo, sendo os casos decididos pela justiça comum.
} 
$\mathrm{O}$ ciclo de auditoria se estende por vários anos, não existindo um foco em um ano específico ou período legislativo específico, a não ser no que se refere a conta geral do estado. Consistente com sua missão institucional judicial originária, o foco é na auditoria de conformidade. Por sua vez, o perfil profissional é marcado pelo predomínio profissional de bacharéis em direito e oficiais de justiça.

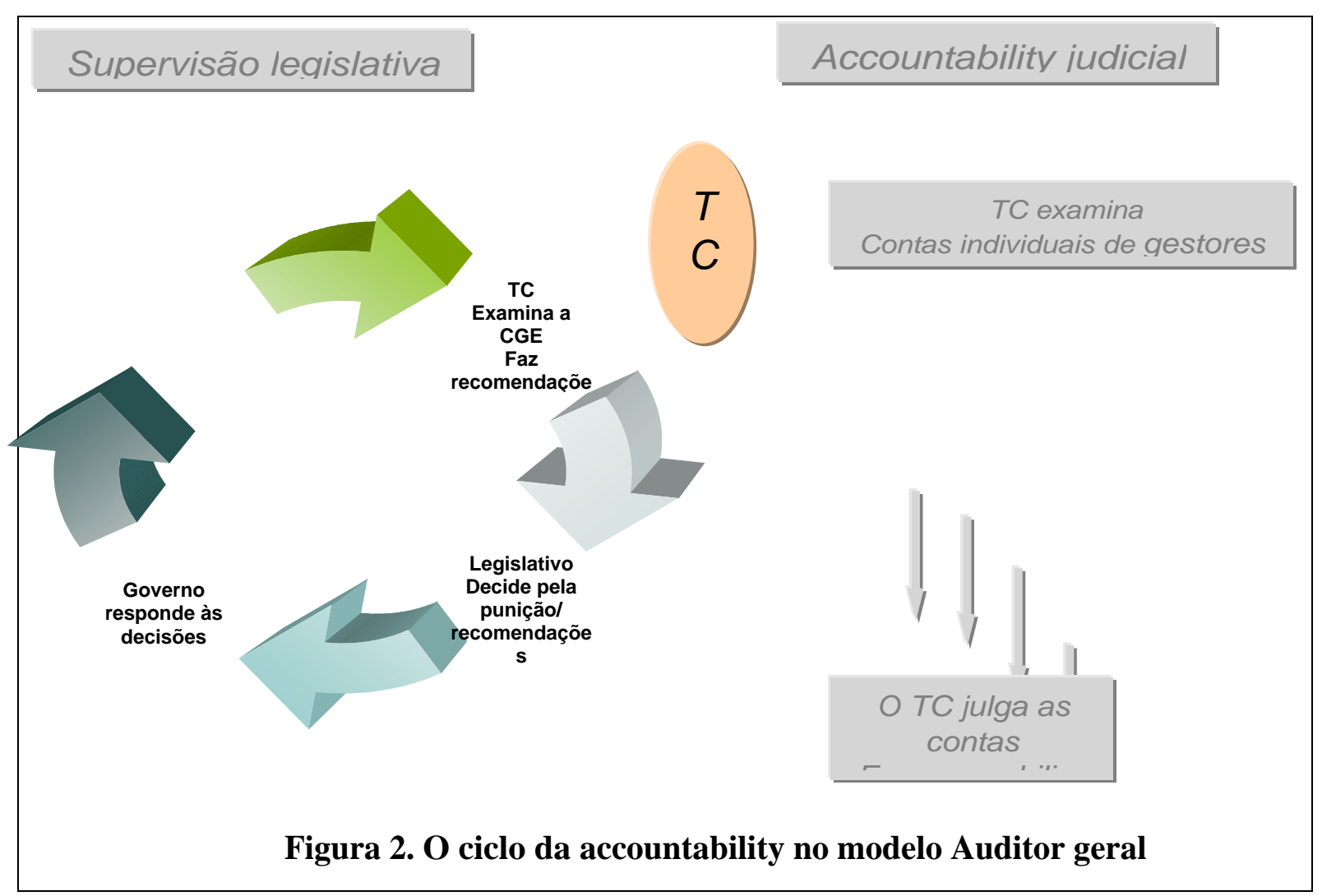




\section{Tabela 1. Características Selecionadas e Tipo de ISC}

\begin{tabular}{|c|c|c|c|}
\hline \multirow{2}{*}{$\begin{array}{r}\text { Caracter } \\
\text { isticas selecionadas }\end{array}$} & \multicolumn{3}{|l|}{ TIPO DE ISC } \\
\hline & Auditor General & Tribunal de Contas & $\begin{array}{l}\text { Audit Board } \\
\text { Conselho de Contas }\end{array}$ \\
\hline Missão & $\begin{array}{l}\text { Auxiliar o legislativo no } \\
\text { controle das contas do executivo } \\
\text { emitindo recomendações }\end{array}$ & $\begin{array}{l}\text { Auxiliar o legislativo no } \\
\text { controle das contas do executivo mas } \\
\text { também exercendo } \\
\text { jurisdicional }\end{array}$ & $\begin{array}{l}\text { Auxiliar o legislativo no } \\
\text { controle das contas do executivo } \\
\text { emitindo recomendações }\end{array}$ \\
\hline $\begin{array}{l}\text { Estrutur } \\
\text { a organizacional }\end{array}$ & $\begin{array}{l}\text { A ISC é parte integral da } \\
\text { função de controle do poder } \\
\text { legislativo e é dirigida por Auditor } \\
\text { e/ ou comptroller com grandes } \\
\text { poderes individuais }\end{array}$ & $\begin{array}{l}\text { A ISC é parte auxiliar da } \\
\text { função de controle do poder } \\
\text { legislativo mas exerce funções } \\
\text { judiciais e têm status de magistratura }\end{array}$ & \begin{tabular}{lcr}
\multicolumn{1}{c}{ Board } & de & auditores \\
independentes, & indicados & e/ ou \\
nomeados pelo & Presidente & e/ ou \\
aprovados pelo Legislativo &
\end{tabular} \\
\hline $\begin{array}{lr} & \text { Articula } \\
\text { ção } & \text { com } \\
\text { Legislativo } & \end{array}$ & $\begin{array}{l}\text { Estreita através de uma } \\
\text { Comissão de Contas Públicas (Public } \\
\text { Accounts Committees) ou Comissão } \\
\text { de Plano e Orçamento }\end{array}$ & 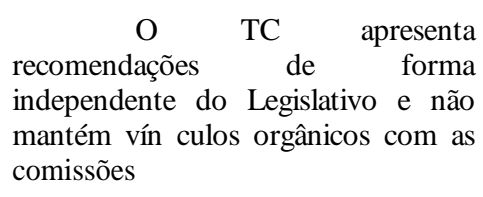 & $\begin{array}{l}\text { Estreita através de uma } \\
\text { Comissão de Contas Públicas (Public } \\
\text { Accounts Committees) ou Comissão de } \\
\text { Plano e Orçamento }\end{array}$ \\
\hline Foco & Auditoria financeira & Análise de conformidade & Variável \\
\hline $\begin{array}{l}\text { Tipo de } \\
\text { auditoria }\end{array}$ & $\begin{array}{l}\text { Financeira } \text { e de } \\
\text { performance }\end{array}$ & $\begin{array}{llll}\text { Legal idade } & \text { e } & \text { de } \\
\text { conformidade } & & & \end{array}$ & Variável \\
\hline $\begin{array}{l}\text { Mandato } \\
\text { do dirigente }\end{array}$ & $\begin{array}{r}\text { Mandato fixo, mas que } \\
\text { pode ser estendido }\end{array}$ & $\begin{array}{l}\text { Estabilidade até idade de } \\
\text { aposentadoria }\end{array}$ & $\begin{array}{l}\text { Mandato fixo, renovavel na } \\
\text { maioria dos casos }\end{array}$ \\
\hline $\begin{array}{l}\text { Respons } \\
\text { abilização de de } \\
\text { gestores públicos }\end{array}$ & Coletiva e ministerial & $\begin{array}{l}\stackrel{\text { O }}{ } \text { gestor } \\
\text { responsabilizável } \\
\text { pela má gestão de fundos públicos }\end{array}$ & Coletiva e ministerial \\
\hline temporal & Focalizado no ano anterior & $\begin{array}{l}\text { Usualmente refere-se a } \\
\text { vários anos }\end{array}$ & Variado \\
\hline $\begin{array}{l}\text { Predomi } \\
\text { nância profissional } \\
\text { no staff }\end{array}$ & $\begin{array}{l}\text { Auditores, contadores e } \\
\text { economistas }\end{array}$ & Bacharéis em direito & $\begin{array}{l}\text { Auditores, contadores } \\
\text { economistas }\end{array}$ \\
\hline $\begin{array}{l}\text { Resultad } \\
\text { o final da ação da } \\
\text { ISC }\end{array}$ & $\begin{array}{l}\text { Recomendação } \\
\text { Parlamento,que determina funções } \\
\text { cabíveis }\end{array}$ & $\begin{array}{l}\text { Recomendação } \\
\text { Parlamento que determina funções } \\
\text { cabíveis quanto a Conta Geral do } \\
\text { Estado, e julgamento em última } \\
\text { instância de auditorias e } \\
\text { irregularidades de agentes públicos } \\
\text { com proferimento de sentença }\end{array}$ & \begin{tabular}{l}
\multicolumn{2}{c}{ Recomendação $r$} \\
Parlamento,que determina funções \\
cabíveis
\end{tabular} \\
\hline $\begin{array}{l}\text { Países e } \\
\text { regiões } \\
\text { predominam }\end{array}$ & $\begin{array}{l}\text { Inglaterra, Suécia, África do } \\
\text { Sul, Canadá, Austrália, Chile** }\end{array}$ & $\begin{array}{c}\text { Uruguai*, Brasil*, } \\
\text { Moçambique, Portugal, França. }\end{array}$ & $\begin{array}{l}\text { Países } \text { Baixos, } \\
\text { alemanha, Japão, Coréia }\end{array}$ \\
\hline
\end{tabular}


* Uruguai e Brasil utilizam um sistema híbrido de TC onde este não exerce controle jurisdicional

** Embora o formato institucional seja de Auditor Geral, a CGRC também opera como Tribunal de Contas

Fontes :

National Audit Office (2005) State A udit in the European Union, London; Dfid (2004) CharacteristISC of different external audit systems, London, Briefing; Wang, D and L Rakner (2005) The accountability function of supreme audit institutions in Malawi, Uganda and Tanzania, CMI Report R2005: 4, Oslo, Christian Michelsen Institute; websites das ISCs; Santiso (2007)

O modelo de Audit Board (Conselho de Contas) mantém estreita relação com o de auditor-geral, exceto pela existência de um colegiado de auditores que dirigem a instituição. Em alguns casos, há forte independência e autonomia de cada auditor geral em relação a seus planos de trabalho. Em outros o colegiado atua conjuntamente. Os mandatos dos membros podem variar e serem ou não não-coincidentes. $O$ foco do trabalho bem como o perfil profissional varia amplamente segundo o caso.

A análise comparativa empreendida nesta seção permite duas conclusões importantes. Em primeiro lugar, o modelo de Tribunal de Contas exige um duplo foco na tarefa avaliativa. Por um lado, o papel da ISC no seu papel de apoio à supervisão legislativa. Por outro, a eficiência e eficácia da ISC em exercer o papel de controle jurisdicional da utilização de recursos pelos gestores públicos

Os modelos de ISCs representam desenhos institucionais específicos cuja adoção e mudanças ao longo do tempo mantém estreita relação com a arquitetura constitucional e tradições jurídicas e políticas dos países. A despeito dessa variabilidade é possível analisar estes modelos em seus próprios termos, avaliando-se os pré-requisitos gerais ou sistêmicos necessários para o seu funcionamento efetivo (Cf Tabela 2). Este exercício possibilita, sobretudo, uma avaliação do macro-ambiente em que se inserem as ISCs. 


\section{Tabela 2. Requisitos Sistêmicos para a efetividade do controle}

\begin{tabular}{|c|c|c|}
\hline Instância & $\begin{array}{l}\text { Modelo Westminster } \\
\text { (Auditor/General /Board) }\end{array}$ & Modelo Tribunal de Contas \\
\hline Legislativo & $\begin{array}{l}\text { Competição política forte e normas } \\
\text { efetivas de inclusão da oposição no sistema de } \\
\text { controle } \\
\text { Ex. Líder da oposição preside o } \\
\text { Comitê de Contas Públicas (Reino Unido) } \\
\text { Contra-exemplo. O Auditor geral é } \\
\text { controlado pelo Executivo (Uganda). }\end{array}$ & $\begin{array}{l}\text { Forte Independência do Judiciario } \\
\text { frente ao Executivo }+ \text { competição política } \\
\text { moderada } \\
\text { Ex.Portugal }\end{array}$ \\
\hline Dirigentes da & $\begin{array}{l}\text { Existência de incentivos sociais e } \\
\text { institucionais de controle da ação do Auditor }\end{array}$ & $\begin{array}{l}\text { Juízes independentes com incentivos } \\
\text { internos e externos para impor sanções } \\
\text { Contra-exemplo. TCs de alguns } \\
\text { estados brasileiros }\end{array}$ \\
\hline Cidadãos & $\begin{array}{l}\text { Níveis elevados de accountability societal } \\
\text { Legislativo ter incentivos eleitorais } \\
\text { para estabelecer sanções decorrentes da } \\
\text { publicização dos resultados das auditorias } \\
\text { Ex. democracias industriais } \\
\text { Contra-exemplo ISC em democracias } \\
\text { pouco consolidadas. }\end{array}$ & $\begin{array}{l}\text { Níveis moderados de accountability } \\
\text { societal } \\
\text { Influência societal moderada sobre } \\
\text { judiciário decorrentes da publicização dos } \\
\text { resultados das auditorias } \\
\text { Ex. democracias } \\
\text { Contra-exemplo ISC em } \\
\text { democracias pouco consolidadas. }\end{array}$ \\
\hline
\end{tabular}

O primeiro aspecto relevante a ser considerado é que um pressuposto essencial para o bom funcionamento do modelo auditor geral diz respeito ao funcionamento do legislativo e ao sistema partidário. Nesse sentido é necessário que haja um consenso mínimo enraizado entre os partidos políticos principais em relação à punição de atos de corrupção. Os partidos políticos podem diferir em aspectos programáticos das políticas e divergirem sobre a 
efetividade das políticas públicas. Mas esse consenso em torno da intolerância frente à corrupção é fundamental para garantir efetividade ao controle externo. Em contextos nos quais a opinião pública seja informada e ativa, os partidos políticos tendem a preferir punição a corrupção em suas próprias bases (ou envolvendo seus correligionários) à associação com práticas corruptas, em virtude das repercussões eleitorais dessa associação.

O segundo aspecto é que como a efetividade dos resultados do trabalho de controle externo depende essencialmente do comportamento do Legislativo, que é a instância responsável pela responsabilização, é fundamental que este último tenha incentivos para sancionar os desvios ou o desperdício de fundos públicos. Em sistemas presidencialistas a formação do governo independe do resultado das eleições legislativas. Em sistemas semipresidencialistas e parlamentaristas o resultado das eleições é fundamental. Nestes últimos, a maioria parlamentar que dá sustentação política ao Gabinete não tem incentivos para promover a responsabilização porque os custos políticos incorridos pelo governo também afetam por extensão sua base parlamentar. ${ }^{5} \mathrm{O}$ destino político dos partidos majoritários e seus representantes estão intrinsecamente entrelaçados com os do governo. "Daí não ser surpresa que os membros do Parlamento que representam o governo raramente demonstram coragem para apoiar a crítica articulada pela ISC, e muito menos para usar o arsenal de instrumentos legislativos para controlar ou sancionar o governo". ${ }^{6}$

Neste sentido, apenas os partidos da oposição têm incentivos para promover a responsabilização. ${ }^{7} \mathrm{Na}$ realidade a prática institucional de muitos países obedece a este requisito de incluir ativamente a oposição nos trabalhos de controle. No Reino Unido e Argentina, cabe à oposição parlamentar presidir a Comissão legislativa relevante e indicar o Auditor geral. A conclusão geral que se pode extrair destas considerações é que a oposição cumpre papel decisivo nas SCIs. Como Fiedler argumenta,

"Portanto, cabe essencialmente à oposição parlamentar não só usar os relatórios da ISC e utilizar suas conclusões e críticas como um instrumento no debate parlamentar, como também em relação às questões de política pública. Não é necessário reafirmar que os partidos de oposição - da mesma forma que os partidos

5 Strom, K., Miller, W. and Bergman, T. (eds), Delegation and accountability in parliamentary democracies. Oxford and New York: Oxford University Press, 2003.

${ }^{6}$ Fiedler, Franz (2004) "The independence of audit institutions", in INTOSA I 50 years 1952-2003, Oslo, 108-121.

7. Fiedler, Franz (2004), op.cit. Isto vale para países presidencialistas e parlamentaristas mas este efeito é mais intenso sob o primeiro.. 
governistas com seus interesses opostos - são movidos por considerações práticas da política partidária e não por algum interesse específico na auditoria governamental. No entanto, há uma convergência de interesses entre a auditoria e a oposição parlamentar, a qual leva inegavelmente a uma relação íntima entre ambos". ${ }^{8}$

Em terceiro lugar, é essencial que haja limites claros à ação do auditor geral. Ao investir um único indivíduo com amplos poderes discricionários, corre-se o risco de abuso desses poderes. Neste caso outras formas colegiadas ou judiciais de controle podem ser mais apropriadas ${ }^{9}$. Em quarto lugar, para que possa alcançar efetividade o modelo de Auditor Geral pressupõe que as conclusões e recomendações sejam publicizadas amplamente e logrem discussão pública. $\mathrm{O}$ fato de que o ciclo de controle estar concentrado no tempo - e se restringir apenas a um ano - reforça a necessidade de que a publicização dos resultados ocorra também de forma concentrada e simultânea. Só neste contexto o Parlamento terá efetivamente incentivos a agir. Neste sentido, a mídia e as ONGs adquirem grande centralidade no processo de controle de governos ao promover a acountabilty societal.

Nos modelos de Tribunais de Contas, com poderes jurisdicionais, a efetividade depende menos do Parlamento do que no modelo anterior. Todavia, no caso do julgamento da conta geral do estado, cabe ao Legislativo aplicar sanções. A diferença é, portanto de nível de envolvimento do Legislativo, menor no caso do modelo de Tribunal de Contas. As sanções são em princípio auto-aplicáveis no caso de contas comuns porque estas estão tipificadas em lei e o Tribunal como instituição judicial dá seguimento automático ao julgamento independente de influências externas. Como poder independente e órgão de soberania, o Tribunal é plenamente autônomo e suas prerrogativas de independência - mandatos vitalícios etc.- são ainda mais expressivas do que no modelo Auditor Geral. Neste sentido há potencialmente menos desincentivos à sanção por parte das bases de sustentação do governo. No entanto, os juízes são em geral nomeados pelo Executivo e confirmados pelo poder Legislativo.

A efetividade das ações de controle externo neste modelo depende do grau de independência alcançado pelo Judiciário como instituição e pela ISC como parte deste poder. Em democracias jovens, como as novas democracias africanas e latino-americanas, o

\footnotetext{
8 op cit.

${ }^{9}$ Wang, D and L Rakner (2005) The accountability function of supreme audit institutions in Malawi, Uganda and Tanzania, op. cit. Dfid (2004) CharacteristISC of different external audit systems, op. cit.
} 
fortalecimento do judiciário e o desenvolvimento da capacidade de efetivamente levar a cabo a punição de abusos praticados pelos governantes são dimensões essenciais do processo de consolidação democrática. A publicização das atividades de controle externo em ambos os modelos - auditor geral e tribunal de contas - tem repercussões relevantes sobre a efetividade do controle. Essa publicização deve alcançar sobretudo o próprio Tribunal, levando-o a levar a cabo sanções. A publicização e a accountability societal são portanto essenciais considerando o risco do trabalho do Tribunal ter baixa visibilidade pública e baixa capacidade de enforcement de sanções, como é o caso de muitos tribunais no mundo em desenvolvimento. Nestes casos não há envolvimento de nenhum stakeholder relevante - nem o legislativo, nem a sociedade civil organizada. As recomendações e sanções do Tribunal acabam não tendo credibilidade.

A principal conclusão a ser extraída da análise nesta seção portanto é que em contextos de forte polarização política ou de multipartidarismo pouco institucionalizado como é comum na África Sub-Saariana ou em alguns países latino-americanos o macroambiente político constituiu forte obstáculo a uma atuação efetiva do modelo de ISC fundado no auditor geral.

\section{As Instituições de Controle Externo na América Latina}

O panorama das instituições de controle na América Latina bastante diversificado não só no que diz respeito ao formato mas também em relação ao grau de maturidade institucional alcançado. Como se pode observar no quadro, dentre 18 países, 3 utilizam o modelo Tribunal de Contas (Brasil, Uruguai e Honduras), 3 utilizam o modelo de Audit Board (Argentina, República Dominicana, Nicarágua) e os demais utilizam o modelo de Auditor General (cf Quadro 1 e 2). O modelo histórico na região foi o de Tribunais de Contas, mas ao longo do tempo 9 paises transformaram seus Tribunais para o modelo colegial ou monocrático de contraloria. Em vários países, como o Chile, Bolívia e o Peru, esta mudança ocorreu no marco da Kemmerer Mission, do governo americano na década de 20. Nesta missão o governo americano forneceu assistência técnica a vários países da região com base nas mudanças introduzidas pelo governo americano no inicio daquela década no arcabouço legal e institucional do orçamento e das finanças publicas. No período recente a experiência reformista de mudança radical de modelo limitou-se apenas à Argentina, que adotou o modelo de Audit Board no bojo das reformas de mercado introduzidas pelo Governo Menem. 
Quadro 1. legal das Instituições de Controle Externo na América Latina

\begin{tabular}{|c|c|c|c|c|}
\hline Países & Clausulas Constitucionais & $\begin{array}{c}\text { Financial administration law or } \\
\text { Organic budget law }\end{array}$ & Lei Orgânica ( local de Aplicação) & $\begin{array}{c}\text { Antecessores (depois da } \\
\text { Independência) }\end{array}$ \\
\hline $\begin{array}{l}\text { Argentina } \\
\text { Auditoria General de la Nación, } \\
\text { AGN }\end{array}$ & Constituição de 1994, art. 85 & $\begin{array}{l}\text { Ley de administración financiera y de los sistemas de } \\
\text { control del sector público, 24156, 1992; Ley } \\
\text { Complementaria Permanente de Presupuesto, } 1997\end{array}$ & & $\begin{array}{l}\text { Tribunal de Cuentas de la Nación, } \\
1956\end{array}$ \\
\hline $\begin{array}{l}\text { Bolívia } \\
\text { Contraloría General de la } \\
\text { República, CGR }\end{array}$ & Constituição de 1967, art. 154-155 & $\begin{array}{l}\text { Ley de Administración y Control Gubernamentales, } \\
\text { SAFCO, } 1990\end{array}$ & $\begin{array}{l}\text { Ley Orgánica de la Contraloría General de la } \\
\text { República, 1977; } \\
\text { Reglamento para el Ejercicio de las } \\
\text { Atribuciones de la Contraloria General de la } \\
\text { República, } 1992\end{array}$ & $\begin{array}{l}\text { Tribunal Nacional de Cuentas, } 1883 \text {; } \\
\text { Contraloría General de la República, } \\
1928 .\end{array}$ \\
\hline $\begin{array}{l}\text { Brasil } \\
\text { Tribunal de Contas da União, } \\
\text { TCU }\end{array}$ & Constituição de 1988, art. $71-75$ and 161 & Ley 10180, 2001 & $\begin{array}{l}\text { Lei Orgânica do Tribunal de Contas da } \\
\text { União, } 1992\end{array}$ & Tribunal de Contas da União, 1891 \\
\hline $\begin{array}{l}\text { Chile } \\
\text { Contraloría General de la } \\
\text { República, CGR }\end{array}$ & Constituição de 1980, art. 87-89 & $\begin{array}{l}\text { Ley Orgánica de Administración Financiera, LOAF, } \\
1975\end{array}$ & $\begin{array}{l}\text { Ley de Organización y Atribuciones de la } \\
\text { Contraloría General de la República, 1953, } \\
\text { reformed in } 1964\end{array}$ & $\begin{array}{l}\text { Contaduría Mayor y Tribunal de } \\
\text { Cuentas, 1839; Tribunal de Cuentas, } \\
\text { 1888; Contraloría General de la } \\
\text { República, } 1927\end{array}$ \\
\hline $\begin{array}{l}\text { Colômbia } \\
\text { Contraloría General de la } \\
\text { República, CGR }\end{array}$ & Constituição de 1991, art.267-268 & Ley 819,2003 & $\begin{array}{l}\text { Ley } 42 \text { (reformulated), 1993; Ley 106, 1993; } \\
\text { amended 1999, } 2000\end{array}$ & $\begin{array}{l}\text { Contaduría General de Hacienda, } \\
\text { 1821; Corte de Cuentas, } 1847 ; \\
\text { Departamento de Contraloría, } 1923\end{array}$ \\
\hline $\begin{array}{l}\text { Costa Rica } \\
\text { Contraloría General de la } \\
\text { República, CGR }\end{array}$ & Constituição de 1949, art. 183-184 & $\begin{array}{l}\text { Ley de Administración Financiera de la República y de } \\
\text { Presupuestos Públicos, } 2001\end{array}$ & $\begin{array}{l}\text { Ley Orgánica de la Contraloría General de la } \\
\text { República, 1951, } 1994\end{array}$ & $\begin{array}{l}\text { Tribunal de Cuentas, 1825; } \\
\text { Centro de Control, 1945; Contraloría } \\
\text { General de la República, } 1949\end{array}$ \\
\hline $\begin{array}{l}\text { República Dominicana } \\
\text { Cámara de Cuentas de la } \\
\text { República, CCR }\end{array}$ & Constituição de 1966, art. 78-81 and 107 & $\begin{array}{l}\text { Ley Orgánica de Presupuesto para el Sector Público, } \\
1969\end{array}$ & Ley 10-04, 2004 & $\begin{array}{l}\text { Cámara de Cuentas de la República, } \\
1942\end{array}$ \\
\hline $\begin{array}{l}\text { Equador } \\
\text { Contraloría General de la } \\
\text { República, CGR }\end{array}$ & Constituição de 1998, art. 121-122 and 211-213 & $\begin{array}{l}\text { Ley Orgánica de Administración Financiera y Control, } \\
\text { LOAFYC, } 1977(1986,1993)\end{array}$ & $\begin{array}{l}\text { Ley Orgánica de la Contraloría General del } \\
\text { Estado, } 2002\end{array}$ & $\begin{array}{l}\text { Contaduría General de Hacienda, } \\
\text { 1822; Tribunal de Cuentas, 1861; } \\
\text { Contraloría General del Estado, } 1927\end{array}$ \\
\hline $\begin{array}{l}\text { El Salvador } \\
\text { Contraloría General del Estado, } \\
\text { CGE }\end{array}$ & Constituição de 1983, art. 195-199 & $\begin{array}{l}\text { Ley Orgánica de la Administración Financiera del } \\
\text { Estado, } 1995\end{array}$ & $\begin{array}{l}\text { Ley de la Corte de Cuentas de la República, } \\
\text { 1995, } 2002\end{array}$ & $\begin{array}{l}\text { Tribunal Superior de Cuentas, 1872; } \\
\text { Auditoría General de Hacienda, 1930; } \\
\text { Corte de Cuentas de la República, } \\
1939\end{array}$ \\
\hline $\begin{array}{l}\text { Guatemala } \\
\text { Contraloría General de Cuentas, } \\
\text { CGC }\end{array}$ & Constituição de 1985, art. 232-236 & Ley Orgánica de Presupuesto, 1997 & $\begin{array}{l}\text { Ley Orgánica de la Contraloría General de } \\
\text { Cuentas, } 2002\end{array}$ & $\begin{array}{l}\text { Tribunal y Contaduría Mayor de } \\
\text { Cuentas, 1824; Tribunal y Contraloría } \\
\text { de Cuentas, 1945, } 1948\end{array}$ \\
\hline $\begin{array}{l}\text { Honduras } \\
\text { Tribunal Superior de Cuentas, } \\
\text { TSC }\end{array}$ & $\begin{array}{l}\text { Constituição de 1964, reformado in 2002, art. } \\
222-227\end{array}$ & Ley Organica del Presupuesto, 1976 & $\begin{array}{l}\text { Ley Orgánica del Tribunal Superior de } \\
\text { Cuentas, } 2002\end{array}$ & $\begin{array}{l}\text { Tribunal de Cuentas, 1928; } \\
\text { Contraloría General de la República, } \\
1956\end{array}$ \\
\hline $\begin{array}{l}\text { México } \\
\text { Auditoría Superior de la } \\
\text { Federación, ASF }\end{array}$ & $\begin{array}{l}\text { Constituição de 1917, reformada 1999, art. } 73 \text {, } \\
74,78 \text { y } 79\end{array}$ & $\begin{array}{l}\text { Ley de Presupuesto, Contabilidad y Gasto Público } \\
\text { Federal, } 1976 \text { (1995) }\end{array}$ & $\begin{array}{l}\text { Ley de Fiscalización Superior de la } \\
\text { Federación, } 2000\end{array}$ & $\begin{array}{l}\text { Contaduría Mayor de Hacienda, 1824, } \\
\text { 1963, } 1978\end{array}$ \\
\hline $\begin{array}{l}\text { Nicarágua } \\
\text { Contraloría General de la } \\
\text { República, CGR }\end{array}$ & Constituição de 1987, 1995, 200, art. 154-157 & $\begin{array}{l}\text { Ley del Régimen Presupuestario, 1988, } 1991 \\
\text { Ley de administración financiera y del presupuesto } \\
\text { público (Ley 550, 2005) }\end{array}$ & $\begin{array}{l}\text { Ley Orgánica de la Contraloría General de la } \\
\text { República y Systema de Control } \\
\text { gubernamental, 1979, Ley } 3612000\end{array}$ & $\begin{array}{l}\text { Tribunal Supremo de Cuentas de la } \\
\text { República, 1900; } \\
\text { Tribunal de Cuentas, 1930, } 1966 \\
\end{array}$ \\
\hline $\begin{array}{l}\text { Panamá } \\
\text { Contraloría General de la } \\
\text { República, CGR }\end{array}$ & Constituição de 1972, 1978, 1983, art. 275-276 & Ley de Presupuesto, 1999 & $\begin{array}{l}\text { Ley Orgánica de la Contraloría General de la } \\
\text { República, } 1984\end{array}$ & $\begin{array}{l}\text { Visitador Fiscal, 1904; Tribunal de } \\
\text { Cuentas, 1904; Agente Fiscal, 1918; } \\
\text { Oficina de Contabilidad y Contraloría, } \\
\text { 1930; Contraloría General de la } \\
\text { República, } 1942\end{array}$ \\
\hline $\begin{array}{l}\text { Paraguai } \\
\text { Contraloría General de la } \\
\text { República, CGR } \\
\end{array}$ & Constituição de 1992, art. 281-284 & Ley de Administración Financiera del Estado, 1999 & $\begin{array}{l}\text { Ley Orgánica y Funcional de la Contraloría } \\
\text { General de la República, } 1994\end{array}$ & 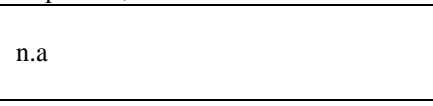 \\
\hline $\begin{array}{l}\text { Peru } \\
\text { Contraloría General de la } \\
\text { República, CGR }\end{array}$ & Constituição de 1993, art. 82 & $\begin{array}{l}\text { Ley marco de la Administración Financiera del Sector } \\
\text { Público, } 2003 . \\
\text { Ley General del Sistema Nacional de Presupuesto, }\end{array}$ & $\begin{array}{l}\text { Ley del Sistema Nacional de Control y de la } \\
\text { Contraloría General de la República, } 2002\end{array}$ & $\begin{array}{l}\text { Tribunal Mayor de Cuentas, } 1823 ; \\
\text { Contraloría General de la República, } \\
1929,1964\end{array}$ \\
\hline
\end{tabular}




\begin{tabular}{|c|c|c|c|c|}
\hline & & 2004 & & \\
\hline $\begin{array}{l}\text { Uruguai } \\
\text { Tribunal de Cuentas, TC }\end{array}$ & Constituição de 1996, art. 208-213 & $\begin{array}{l}\text { Ley de Contabilidad y Administración Financiera, } \\
\text { TOCAF, } 1991 \text { (1999) }\end{array}$ & $\begin{array}{l}\text { Texto Ordenado de Contabilidad y } \\
\text { Administración Financiera, } 1997\end{array}$ & $\begin{array}{l}\text { Comisión de Cuentas, 1830, 1834; } \\
\text { Tribunal de Cuentas, } 1934\end{array}$ \\
\hline $\begin{array}{l}\text { Venezuela } \\
\text { Contraloría General de la } \\
\text { República, CGR }\end{array}$ & Constituição de 2000, art. 287-291 & $\begin{array}{l}\text { Ley Orgánica de la Administración Financiera del } \\
\text { Sector Público, LOAF, } 2003\end{array}$ & $\begin{array}{l}\text { Ley Orgánica de la Contraloría General de la } \\
\text { República y del Sistema Nacional de Control } \\
\text { Fiscal, 2001; Ley Orgánica del Poder } \\
\text { Ciudadano, } 2001\end{array}$ & $\begin{array}{l}\text { Contraloría de la Nación, 1938; } \\
\text { Contraloría General de la República, } \\
1961\end{array}$ \\
\hline
\end{tabular}

Fonte Santiso (2007)

\section{Desenho Institucional das Agências de Auditorias Autônomas na América Latina}

\begin{tabular}{|c|c|c|c|c|c|c|c|}
\hline Países & Nome & Tipo & Liderança & Controle ex antes & $\begin{array}{l}\text { Instituições ligadas } \\
\text { ao } \\
\text { Executivo }\end{array}$ & $\begin{array}{l}\text { Instituições } \\
\text { ligadas ao } \\
\text { Legislativo }\end{array}$ & Poderes semi-judiciai \\
\hline Argentina & $\begin{array}{l}\text { Auditoria General de la Nación, } \\
\text { AGN }\end{array}$ & Colegial & $\begin{array}{l}\text { Board of (conselho de) } 7 \text { Auditores Gerais, liderado pelo } \\
\text { Presidente. }\end{array}$ & & & $\checkmark$ & \\
\hline Bolívia & $\begin{array}{l}\text { Contraloría General de la } \\
\text { República, CGR }\end{array}$ & Uninominal & Comptroller General & & $\checkmark$ & & \\
\hline Brasil & $\begin{array}{l}\text { Tribunal de Contas da União, } \\
\text { TCU }\end{array}$ & Colegial & $\begin{array}{l}\text { Board of (conselho de) } 9 \text { Auditores Gerais ("Ministros"); } \\
\text { Presidentes eleito pelos pares, substituído anualmente. }\end{array}$ & & & $\checkmark$ & $\checkmark$ \\
\hline Chile & $\begin{array}{l}\text { Contraloría General de la } \\
\text { República, CGR }\end{array}$ & Uninominal & Comptroller Geral & $\checkmark$ & & & $\checkmark$ \\
\hline Colômbia & $\begin{array}{l}\text { Contraloría General de la } \\
\text { República, CGR }\end{array}$ & Uninominal & Comptroller Geral & & & & $\checkmark$ \\
\hline Costa Rica & $\begin{array}{l}\text { Contraloría General de la } \\
\text { República, CGR }\end{array}$ & Uninominal & Comptroller Geral & $\checkmark$ & & $\checkmark$ & \\
\hline $\begin{array}{l}\text { República } \\
\text { Dominicana }\end{array}$ & $\begin{array}{l}\text { Cámara de Cuentas de la } \\
\text { República, CCR }\end{array}$ & Colegial & $\begin{array}{l}\text { Board of at least (conselho de) } 5 \text { membros, com Comissão } \\
\text { executiva composta por um Presidente, vice Vice-presidente e } \\
\text { Secretario executivo. }\end{array}$ & $\checkmark$ & & & \\
\hline Equador & $\begin{array}{l}\text { Contraloría General del Estado, } \\
\text { CGE }\end{array}$ & Uninominal & & $\checkmark$ & & & \\
\hline El Salvador & $\begin{array}{l}\text { Corte de Cuentas de la República, } \\
\text { CCR }\end{array}$ & Colegial & $\begin{array}{l}\text { Board of at least (conselho de) } 5 \text { membros, com Comissão } \\
\text { executiva composta por um Presidente, Vice-presidente e um } \\
\text { Secretario executivo. }\end{array}$ & $\checkmark$ & & $\begin{array}{l}\text { Submete } \\
\text { comunicação ao } \\
\text { congresso }\end{array}$ & $\checkmark$ \\
\hline Guatemala & $\begin{array}{l}\text { Contraloría General de Cuentas, } \\
\text { CGC }\end{array}$ & Uninominal & Comptroller General & & & $\checkmark$ & $\checkmark$ \\
\hline Honduras & $\begin{array}{l}\text { Tribunal Superior de Cuentas, } \\
\text { TSC }\end{array}$ & Colegial & Board of (conselho de) 3 membros & & & $\checkmark$ & \\
\hline México & $\begin{array}{l}\text { Auditoría Superior de la } \\
\text { Federación, ASF }\end{array}$ & Uninominal & & & & $\checkmark$ & \\
\hline Nicarágua & $\begin{array}{l}\text { Contraloría General de la } \\
\text { República, CGR }\end{array}$ & Colegial & $\begin{array}{l}\text { Board ("Conselho Superior") de } 5 \text { membros; Presidente e } \\
\text { Vice-presidente eleito pelos pares com o Conselho por um } \\
\text { ano, por maioria simples. }\end{array}$ & & & $\checkmark$ & \\
\hline
\end{tabular}




\begin{tabular}{|c|c|c|c|c|c|c|}
\hline Panamá & $\begin{array}{l}\text { Contraloría General de la } \\
\text { República, CGR }\end{array}$ & Uninominal & & $\checkmark$ & & $\checkmark$ \\
\hline Paraguai & $\begin{array}{l}\text { Contraloría General de la } \\
\text { República, CGR }\end{array}$ & Uninominal & & & $\checkmark$ & \\
\hline Peru & $\begin{array}{l}\text { Contraloría General de la } \\
\text { República, CGR }\end{array}$ & Uninominal & & $\checkmark$ & & \\
\hline Uruguai & Tribunal de Cuentas, TC & Colegial & $\begin{array}{l}\text { Board of (conselho de) } 7 \text { membros ( } 5+2 \text { desde } 1952) \text {; } \\
\text { Presidente designado pelos pares com o Board. }\end{array}$ & & $\checkmark$ & \\
\hline Venezuela & $\begin{array}{l}\text { Contraloría General de la } \\
\text { República, CGR }\end{array}$ & Uninominal & & & & $\checkmark$ \\
\hline
\end{tabular}

Santiso (2007) 
Existem muitas instituições de controle externo no nível subnacional na América Latina, as quais se concentram no Brasil e na Argentina. No Brasil, há 23 tribunais de contas estaduais e dois municipais, além de em 4 estados existir um tribunal com jurisdição sobre os municípios, e outro com jurisdição exclusiva sobre as contas estaduais, totalizando 33 instituições (Tabela 3). Na Argentina, existe maior diversidade de modelos porque embora o modelo adotado no nível federal seja de Audit board, no plano subnacional prevalece o modelo de tribunal de contas, salvo na Ciudad Autônoma de Buenos Ayres (que se emancipou em 1996, levando à criacãHá instituições de controle provinciais, sendo 20 tribunais de contas e uma auditoria segundo o modelo Audit Board na província de Salta (Tabela 4). No nível municipal, há .18 instituições, sendo todas tribunais de contas e apenas uma adota o modelo de Audit Board. 
Tabela 3. Tribunais de contas subnacionais no Brasil

\begin{tabular}{|c|c|c|c|c|}
\hline $\begin{array}{l}\text { Estado/ } \\
\text { municipio }\end{array}$ & $\begin{array}{l}\text { data de } \\
\text { criação }\end{array}$ & $\begin{array}{c}\text { Número de } \\
\text { entidades } \\
\text { jurisdicionadas }\end{array}$ & $\begin{array}{l}\text { Numero de } \\
\text { funcionários }\end{array}$ & $\begin{array}{c}\text { Orçamento do TC como } \\
\% \text { orçamento estadual }\end{array}$ \\
\hline \multicolumn{5}{|c|}{ Entidades Estaduais Com Jurisdição sobre Governo dos Estados e Municipios } \\
\hline TCE-AC & 1987 & 207 & 149 & 1.16 \\
\hline TCE-AL & 1947 & 256 & 681 & 0.87 \\
\hline TCE-AM & 1950 & 282 & 515 & 1.48 \\
\hline TCE-AP & 1991 & 120 & & 2.12 \\
\hline TCEE-BA & 1915 & 380 & 720 & 0.45 \\
\hline TCEE-CE & 1935 & 119 & 205 & 0.28 \\
\hline TC-DF & 1960 & 124 & 589 & 2.32 \\
\hline TCE-ES & 1954 & 386 & 484 & 0.81 \\
\hline TCEE-GO & 1947 & 49 & 507 & 0.95 \\
\hline TCE-MA & 1946 & 518 & 306 & 0.98 \\
\hline TCE-MG & 1935 & 2.196 & 1.291 & 0.89 \\
\hline TCE-MS & 1979 & 630 & 428 & 2.55 \\
\hline TCEE-PA & 1947 & 81 & & 1.34 \\
\hline TC-PE & 1968 & 720 & 616 & 1.47 \\
\hline TCE-PB & 1970 & 650 & 352 & 1.05 \\
\hline TCE-PI & 1891 & 1.174 & 104 & 0.72 \\
\hline TCE-PR & 1947 & 1.330 & 477 & 0.93 \\
\hline TCE-RJ & 1947 & 640 & 240 & 0.80 \\
\hline TCE-RN & 1957 & 452 & 332 & 0.92 \\
\hline TCE-RO & 1983 & 203 & 284 & 1.54 \\
\hline TCE-RR & 1988 & 85 & 206 & 1.69 \\
\hline TCE-RS & 1935 & 1.218 & 1.005 & 1.01 \\
\hline TCE-SC & 1955 & 1.871 & 451 & 0.74 \\
\hline TCE-SE & 1969 & 235 & 353 & 1.88 \\
\hline TCE-SP & 1921 & 3.021 & 1364 & 0.34 \\
\hline TCE-TO & 1989 & 350 & 356 & 0.84 \\
\hline TCE-MT & 1953 & 497 & 400 & 1.61 \\
\hline \multicolumn{5}{|c|}{ Entidades estaduais com jurisdição sobre Municípios } \\
\hline TCM-BA & 1980 & 954 & 449 & 0.27 \\
\hline TCM-CE & 1954 & 1.584 & 300 & 0.22 \\
\hline TCM-GO & 1977 & 1.204 & 293 & 0.57 \\
\hline TCM-PA & 1980 & 630 & 177 & 0.77 \\
\hline \multicolumn{5}{|c|}{ Municipais } \\
\hline TCM- SP & 1968 & & & \\
\hline TCM- RJ & 1980 & & & \\
\hline
\end{tabular}

Fonte Melo, Figueiredo e Pereira 2005 
Tabela 4. Instituições subnacionais de controle externo na Argentina

\begin{tabular}{|c|c|c|}
\hline $\begin{array}{l}\text { Província/ } \\
\text { municipalidad }\end{array}$ & $\begin{array}{l}\text { Data de } \\
\text { criação }\end{array}$ & Nome \\
\hline \multicolumn{3}{|c|}{ Provinciais } \\
\hline Catamarca & & Tribunal de Cuentas \\
\hline Córdoba & & Tribunal de Cuentas \\
\hline Buenos Ayres & & Tribunal de Cuentas \\
\hline Corrientes & & Tribunal de Cuentas \\
\hline Chaco & & Tribunal de Cuentas \\
\hline Chubut & & Tribunal de Cuentas \\
\hline Formosa & & Tribunal de Cuentas \\
\hline Jujuy & & Tribunal de Cuentas \\
\hline La Pampa & & Tribunal de Cuentas \\
\hline Mendoza & & Tribunal de Cuentas \\
\hline La Rioja & & Tribunal de Cuentas \\
\hline Misiones & & Tribunal de Cuentas \\
\hline Neuquén & & Tribunal de Cuentas \\
\hline San Luis & & Tribunal de Cuentas \\
\hline San Juan & & Tribunal de Cuentas \\
\hline Santa Cruz & & Tribunal de Cuentas \\
\hline Santa Fé & & Tribunal de Cuentas \\
\hline Santiago del Estero & & Tribunal de Cuentas \\
\hline Tucuman & 1972 & Tribunal de Cuentas \\
\hline Tierra del Fuego & & Tribunal de Cuentas \\
\hline Salta & & Auditoria General \\
\hline \multicolumn{3}{|c|}{ Municipais } \\
\hline Ciudad de Buenos Ayres & 1999 & $\begin{array}{c}\text { Auditoria general de la Ciudad de } \\
\text { Buenos Ayres }\end{array}$ \\
\hline San Francisco & & Tribunal de Cuentas \\
\hline Cosquin & & Tribunal de Cuentas \\
\hline Córdoba & & Tribunal de Cuentas \\
\hline Rio Cuarto & & Tribunal de Cuentas \\
\hline Alta Gracia & & Tribunal de Cuentas \\
\hline La Rioja & & Tribunal de Cuentas \\
\hline Rosario & & Tribunal de Cuentas \\
\hline General Roca & & Tribunal de Cuentas \\
\hline Salta & & Tribunal de Cuentas \\
\hline Santa Fé & & Tribunal de Cuentas \\
\hline San Luis & & Tribunal de Cuentas \\
\hline Villa Mercedes & & Tribunal de Cuentas \\
\hline Santiago del Estero & & Tribunal de Cuentas \\
\hline La Banda & & Tribunal de Cuentas \\
\hline Bariloche & & Tribunal de Cuentas \\
\hline Comodoro Rovadavia & & Tribunal de Cuentas \\
\hline Trelew & & Tribunal de Cuentas \\
\hline
\end{tabular}

Fonte: Secretariado Permanente de lãs tribunales de cuentas 
Como se pode verificar na Figura abaixo, em termos de países do terceiro mundo as ISCs latino-americanas não apresentam desempenho superior as suas congêneres africanas. As ISCs do Egito ou Quênia apresentam maior capacidade institucional que muitas latinoamericanas, incluindo a Argentina.

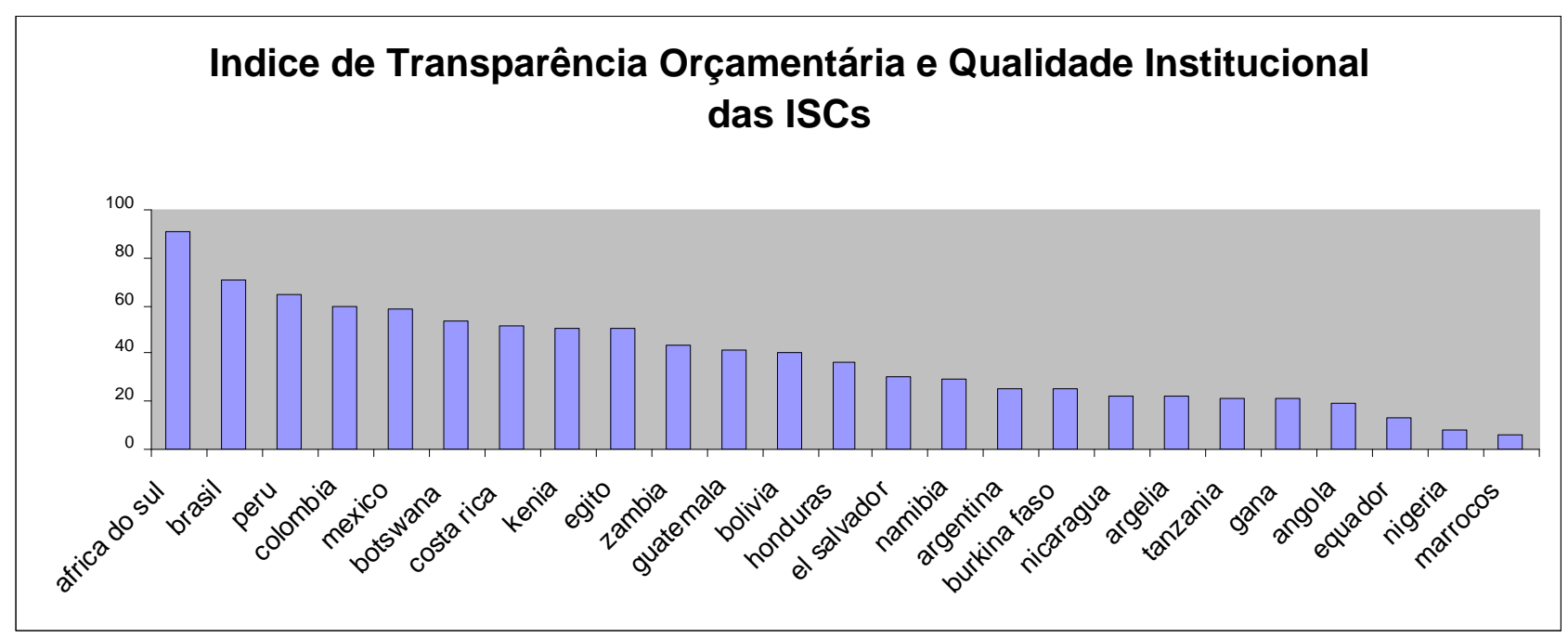

Figura 3. Índice de Controle Externo- países da AL e África

Fonte: elaboração própria do autor com base nos dados do World Bank;Open budget project para 2006 Cf questões do survey no anexo 1.

Em análise comparativa Santiso (2007) avaliou a qualidade institucional das agências de controle na região (cf Figura 4 e Tabela 5). Para tanto o autor construiu uma metodologia centrada em 4 indicadores básicos. independência, tempestividade, credibilidade e enforcement. ${ }^{10} \mathrm{~A}$ independência refere-se ao grau de autonomia da instituição em relação ao poder executivo. Esta autonomia se expressa na forma de nomeação dos seus dirigentes, e da autonomia orçamentária e operacional da instituição. A tempestividade refere-se à celeridade com seus relatórios são produzidos. O pressuposto básico é que quando os relatórios das agências são produzidos com celeridade, a efetividade potencial de suas recomendações é elevada. Caso contrário, perdem efetividade e não produzem impactos. A credibilidade, por sua vez, refere-se a percepção por autores relevantes quanto à qualidade técnica e credibilidade

\footnotetext{
${ }^{10}$ Para detalhes da metodologia cf. Santiso (2007).
} 
institucional do órgão de auditoria. ${ }^{11} \mathrm{O}$ enforcement das decisões refere-se ao poderes legais que as instituições possuem quanto a fazer valer suas recomendações e decisões. ${ }^{12}$

Segundo esta metodologia, as instituições de controle mais efetivas no quadro regional: Brasil, Chile, Costa Rica e Colômbia. Por outro lado, as instituições mais débeis podem ser encontradas em países como Argentina, Peru, Equador, e até recentemente o México. Pode-se observar que o ranking das instituições não sugere nenhuma correlação com o modelo institucional adotado. Os dois países com escores mais elevados - Chile e Brasil - adotam formatos distintos (Tribunal de Contas e Contraloria). Da mesma forma, os piores escores correspondem a formatos institucionais díspares - A udit Board e Tribunal de Contas respectivamente (Argentina e Equador). Esta constatação sugere portanto que outras variaveis interferem no desempenho institucional.

Os dados também são reveladores de que há forte correlação entre níveis de corrupção em um país e qualidade institucional do controle externo. Embora a causalidade não possa ser estabelecida com segurança, esta constatação sinaliza para possíveis efeitos dissuadores da ação de instituições de controle sobre ilícitos cometidos por agentes públicos. Instituições dotadas de maior credibilidade, capacidade de fazer decisões, eficientes e independentes portanto parecem desempenhar importante papel no combate à corrupção.

Figura 4.

Índice de efetividade das Instituições de Controle Externo na América Latina

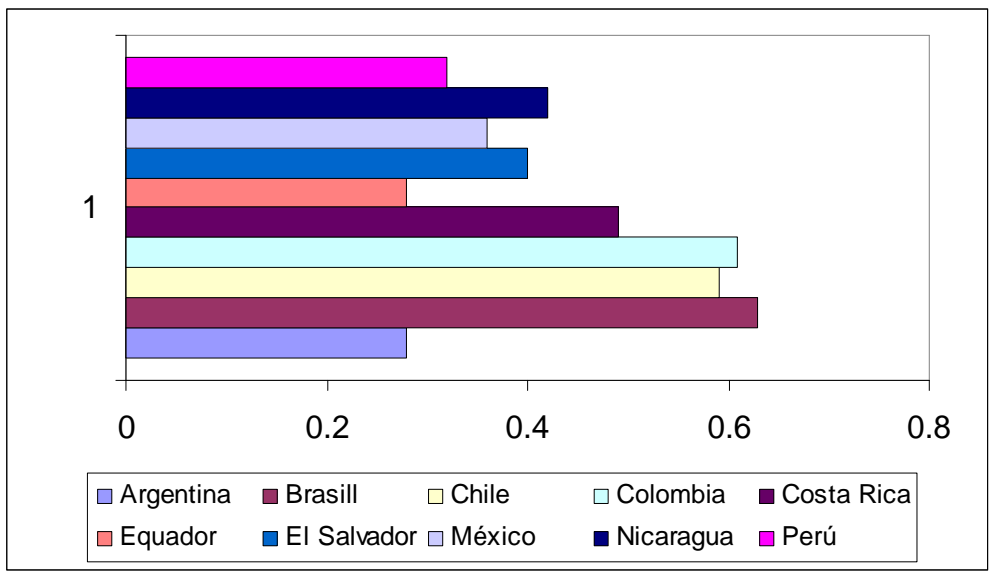

\footnotetext{
${ }^{11}$ Estes dois últimos indicadores são produzidos no marcos da pesquisa Latin America Budget Transparency

$12 \mathrm{O}$ indicador utilizado é o disponibilizado pelo PNUD no projeto Democracia na América Latina.
} 
Fonte Santiso (2007)

Tabela 5

Índice de efetividade das Instituições de Controle Externo na América Latina

\begin{tabular}{lrrrrr} 
Países & Escore & Independência & Credibilidade & Tempestividade & Enforcement \\
\hline Brasil & $\mathbf{0 . 6 3}$ & 0.88 & 0.42 & 0.24 & 1.00 \\
Colômbia & $\mathbf{0 . 6 1}$ & 0.75 & 0.46 & 0.21 & 1.00 \\
Chile & $\mathbf{0 . 5 9}$ & 0.78 & 0.40 & 0.18 & 1.00 \\
Costa Rica & $\mathbf{0 . 4 9}$ & 0.66 & 0.48 & 0.16 & 0.67 \\
Media & & & & & \\
regional & $\mathbf{0 . 4 4}$ & 0.68 & 0.29 & 0.11 & 0.67 \\
Nicarágua & $\mathbf{0 . 4 2}$ & 0.78 & 0.20 & 0.03 & 0.67 \\
El Salvador & $\mathbf{0 . 4 0}$ & 0.53 & 0.08 & 0.00 & 1.00 \\
México & $\mathbf{0 . 3 6}$ & 0.59 & 0.38 & 0.12 & 0.33 \\
Peru & $\mathbf{0 . 3 2}$ & 0.78 & 0.12 & 0.04 & 0.33 \\
Argentina & $\mathbf{0 . 2 8}$ & 0.44 & 0.22 & 0.13 & 0.33 \\
Equador & $\mathbf{0 . 2 8}$ & 0.66 & 0.14 & 0.00 & 0.33 \\
\hline
\end{tabular}

Fonte Santiso 2007

\section{Análise Descritiva dos Casos}

\section{Argentina}

"La A GN está dividida en cotos de caza y nadie pisa la quinta ajena" . (Pagina 12, 31/07/2004).

O caso argentino apresenta lições importantes na medida em que dos três países examinados aqui representa um caso de reforma de modelo institucional. Com efeito, a A uditoria General de la Nación (AGN) foi criado, em meio a uma crise, para substituir o então existente Tribunal de Cuentas de la Nación (TCN). O padrão institucional do novo órgão - seu modelo organizacional e seu funcionamento efetivo - mantém estreita com a esta crise. Faz-se necessário, portanto, reconstituir sumariamente esta crise antes de se passar a análise institucional da AGN. Ele reflete a epigrafe de que a AGN está fragmentada em c 
O TCN foi criado em 1956 como órgão de controle externo delegado, com garantia de independência e estabilidade, separado do órgão de controle interno e dos órgãos de contabilidade publica, e vinculado ao Legislativo. Suas atribuições cobriam o controle da legalidade e legitimidade dos atos administrativos, através do controle prévio e a posteriori. $\mathrm{O}$ Tribunal de Cuentas também exercia funções de tribunal administrativo emitindo juízos de contas e de responsabilidade. Os seus dirigentes, dos quais era exigido formação jurídica e/ ou contábil, eram nomeados pelo Presidente da República e confirmados pelo Senado Federal, gozando de estabilidade no cargo. Com a criação da Corporación de Empresas Nacionales (1974), passou a exercer o controle apenas sobre a administração direta.

O controle prévio de atos do governo pelo Tribunal e que the permite exercer o papel de veto player foi o ponto fundamental que levou à mudança de modelo durante o governo Menem (1989-1989). Durante a transição para a democracia o governo Alfonsín manteve a autonomia do Tribunal e preservou a integridade dos mandatos dos seus membros. No entanto, ao assumir o governo Menem teve que enfrentar a resistência do Tribunal em relação a atos corruptos de sua administração. Entre setembro de 1989 e marco de 1990, o tribunal que Menem havia herdado de Alfonsín, e que continha quatro dos seus cinco membros nomeados pelos governos anteriores, questionou a legalidade de 51 medidas do governo (Chavez 2004, 77). Uma dessas medidas, envolvendo a concessão de um contrato superfaturado e sem licitação no valor de US\$ 3 mi para fornecimento de uniformes escolares escândalo conhecido como caso guardapolvos - foi o estopim da crise envolvendo o tribunal. $\mathrm{O}$ tribunal logrou sustar o contrato após documentar e denunciar graves irregularidades, dentre as quais a falta de especialização e de capital da firma contratada pertecente a membros do circulo menemista. ${ }^{13}$ A resposta do Governo foi a solicitar a renúncia dos 5 membros do Tribunal. Diante da resistência dos ministros, o governo, através do vice-Presidente, Eduardo Duhalde decretou a substituição de quatro dos juízes do Tribunal por indivíduos do circulo político e pessoal do Presidente: dois membros do governo, um assessor do irmão do Presidente, e um amigo pessoal de longa data da província de La Rioja (ibid. 2004; Verbitsky 1993).

Vale registrar que processo semelhante ocorreu com não só a Corte Suprema de la Nación mas também duas instituições de controle (a Fiscalia General de Investigaciones e a Sindicatura Nacional de Empresas Publicas (SNEP) - responsável pelo controle interno dessas empresas,

\footnotetext{
${ }^{13}$ Outro escândalo envolveu sobre preço em contratos na área de saneamento básico (Manzetti 2003).
} 
cujos dirigentes também foram destituídos do cargo. No caso da Fiscalia, cujo dirigente, por lei, desfrutava de estabilidade, Menem teve que recorrer à Suprema Corte, onde passou a desfrutar de "maioria automatica" , para manter sua decisão de demitir o Fiscal General. No caso da SNEP, um órgão subordinado ao Poder Executivo, houve a demissão do cargo de Presidente, após a insistência deste último - antigo tesoureiro de campanha do Menem, em preservar um padrão mínimo de legalidade (suspendendo cerca de 600 atos administrativos, a maioria dos quais relacionados com o processo de privatização (Manzetti 2003).

Após a intervenção no TCN, que gerou uma disputa na suprema corte, o governo propôs um novo modelo para a área do controle, para anular seu papel como veto player. A AGN foi criada pela Lei 24.156/ 92 com um formato institucional de A udit Board. Sua criação ocorreu no marco de uma reforma ampla do marco institucional da administração financeira e do controle prevista nesta Lei. A agência adquiriu status constitucional em 1994 no bojo do conjunto amplo de reformas institucionais aprovadas no marco do Paco de Olivos, pelo qual a oposição Radical barganhou apoio às reformas em troca de maiores medidas de controle sobre o Executivo durante o governo Menem. A estrutura colegiada da AGN consiste de 7 Auditores Gerais, com mandato de 8 anos, sendo permitida a recondução, havendo renovação de $50 \%$ dos membros a cada 4 anos. Para o exercício da função de Auditor Geral é necessário ter a nacionalidade argentina, título universitário em ciências econômicas ou direito, como também comprovada especialização em administração financeira e controle. Dos seis membros do Conselho, três são designados pelo Senado e outros três pela Câmara dos Deputados, de acordo com a proporcionalidade da composição partidária de cada Câmara. A destituição dos membros só é permitida em caso de falta grave ou descumprimento de dever funcional., e com a anuência das duas casas legislativas.

A AGN tem jurisdição sobre todo o setor publico nacional: a administração pública direta, empresas de economia mista e entidades empresariais onde o estado tenha maioria acionária, além de serviços públicos privatizados. Além disso, detém um mandato amplo: pode realizar auditorias de natureza legal, financeira e de gestão como também realizar o controle sucessivo de despesas e receitas públicas.

O sétimo Auditor General é designado para ocupar a presidência da instituição pelo partido político da oposição com maior número de representantes no Legislativo. Sua nomeação é feita por resolução conjunta das Casas Legislativas. Na realidade, como a regra decisória adotada pelo Conselho é a unanimidade, qualquer auditor desempenha o papel de veto 
player, anulando assim o poder associado à prerrogativa exercida pela oposição de indicação do Presidente. Na prática, a maioria legislativa no Legislativo tem controlado a instituição, e tendo em vista que o controle partidário unificado sobre o Executivo e Legislativo tem prevalecido, este arranjo tem garantido que suas recomendações estejam alinhadas com as preferências do Executivo (Santiso 2007). ${ }^{14}$

A transformação do Tribunal de Cuentas na AGN implicou em duas transformações significativas. ${ }^{15}$ A primeira é que a agência perdeu suas prerrogativas de exercer o controle prévio sobre os atos do governo, perdendo assim sua capacidade de exercer o papel de veto player. O controle prévio foi transferido para a Sindicatura Nacional de la Nacion. (SIGEN) - a agência de controle interno, também criada no bojo da Lei 54.156/92. Em segundo lugar, a nova instituição não tinha as prerrogativas quase-judiciais em relação aos atos do governo que o TCN detinha. A AGN não julga contas do governo ou gestores, mas apenas emite dictames (pareceres) a serem apreciados pelas comissões legislativas (Comission Parlamentaria Mixta Revisora de Cuentas y de Presupuesto y Hacienda (CPMRC) do Senado e Câmara do Deputados). ${ }^{16}$

Há forte ambigüidade quanto ao estatuto jurídico da apreciação da conta geral do estado (auenta de inversión) realizada pela CPMRC. A tendência que tem prevalecido é que o Legislativo pode ignorar as recomendações do Tribunal mesmo no que se refere aos questionamentos técnicos quanto a regularidade de contas (Santiso 2007). Vale notar, no entanto que a AGN tem se recusado em apreciar partes das contas do governo porque não há suficiente informação e transparência nas contas públicas. Por outro lado, o Legislativo não

14 Sobre o controle exercido pela AGN cf Santiso 2006; Pessanha 2007 Gonzalez de la Rebella; Depouy 2002)

15 No Senado a maioria justicialista logrou vetar alguma iniciativas da oposição voltadas para garantir maior efetividade à nova agência: "algunas importantes potestades que el proyecto originario de ley le confería en forma explíata a la A GN y que habrían de quedar sepultadas en el debate parlamentario, sobre todo por las reformas introducidas en el Senado: - Mayores facultades para exigir el acceso a la información - Control previo selectivo para operaciones de gran magnitud, - Posibilidad de iniaiar acciones judiaiales para sanaionar

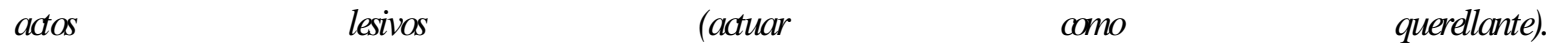
- Separación temporal de los funcionarios que inaurrieran en faltas graves. - -Exigencia de mayores recaudos para la selección de auditores.”Senador Raul Baglini in Lespouy 2002).

16 A CPMRC é composta de 12 membros - seis do senado e seis da câmara - e é presidida pelo representante da maioria (Rodriguez e Bonvecchi 2006).. 
tem apreciado as contas dos governos. O ultimo ano em que isto ocorreu foi 1993 quando as contas de 1997 foram aprovadas cf Tabela 6) (Pessanha 2007). Isto tem ocorrido malgrado o fato que a $\mathrm{AGN}$ preparar seus informes com certa celeridade, o que sugere que o problema está no processo legislativo (Santiso 2007b).

\section{Tabela 6.}

\section{Tramitação das Contas de Inversão do Governo da República Argentina}

\begin{tabular}{|l|l|l|l|}
\hline Cuenta de Inversión & Governo & AGN Data & CN Data \\
\hline 1993 & Menem & Resolução 04/96 & Ley 24.963/98 \\
1994 & Menem & Resolução 124/97 & NA(*) \\
1995 & Menem & Resolução & Resolução 54/00 \\
1996 & Menem & Resolução & NA \\
1997 & Resolução 162/00 & 45/99 & NA \\
1998 & Menem & Resolução 65/00 & Ley 26.098/06 \\
1999 & Mesolução 55/01 & Ley 26.099/06 \\
2000 & Denem & Resolução 28/03 & NA \\
2001 & Resolução 182/03 & NA \\
2002 & DLRua & Resolução 215/04 & NA \\
2003 & Duhalde & Resolução 199/05 & NA \\
2004 & Resolução 37/06 & Resolução 121/06 & NA \\
2005 & NKirchner & NA & NA \\
\hline
\end{tabular}

Fonte: Auditoria General de la Nación.

NA - Não apreciadas até 31 de dezembro de 2006 Fonte Pessanha 2007

Desta forma, a AGN foi criada fundamentalmente como órgão auxiliar do Legislativo, com o objetivo de exercer o controle sucessivo de contas e realizar auditoria de gestão. Como sua capacidade institucional é limitada, suas recomendações não têm poder vinculante, além da supervisão legislativa inoperante, a agência tem pouca capacidade de exercer plenamente seu mandato em relação ao controle.

A relação que a agência mantém com o Legislativo é de forte subordinação (Santiso 2007). Seu plano de auditorias é fortemente influenciado pela CPMRC e seus relatórios de 
auditoria são marcados por intensa politização. ${ }^{17}$ A lógica de estruturação interna dos recursos humanos também é fortemente partidarizada: "La oapación de las casillas siguió una lógica estriđa. Todo gerente radical tendrá un subgerente justicialista, y el jefe de departamento deberá ser radical. y al revés si el gerente es justicialista” ((Pagina 12, 31/ 07/ 2004). Há uma compartimentalização das áreas de atuação de cada auditor, os quais também tem a prerrogativa de indicar os diretores e seus vice dos departamentos de cada área. A assertiva, no epígrafe desta seção, de que as diretorias da AGN são 'reservas privada de caça' (coto de caza) e que ninguém se mete 'no quintal alheio' capta muito apropriadamente a fragmentação causada pela politização..

Como afirma Santiso (2007b, 16)

"The partisanship mode of designation of external auditors leads to a high degree of politiazation of the college of auditors, which is compounded by the politiazation of the agency itself. The A GN is literally 'sliced-up' amongst the two main political parties.16 Furthermore, political parties in the legislature are able to interfere with the auditing process at several stages, from the definition of the agency's work-plan to the follow-up of audit findings. As a result, as confirmed by several auditors-general, audit findings are often negotiated, rather than evaluated on their own merits".

Embora seja um aparato organizacional expressivo - um corpo de 350 funcionários e dotação orçamentária equivalente a $0.3 \%$ do orçamento nacional - a instituição se caracteriza por baixos níveis de profissionalização ${ }^{18}$ e credibilidade. Como parte importante de seu corpo técnico não é estável, flutuando em função dos mandatos dos auditores gerais, sua

17 A imprensa tem documentado o modus operandi politizado da AGN de forma muito gráfica: " ¿Cómo querés que lo arregle ?" es una pregunta que, según fuentes internas, es un clásico en la Auditoría General de la Nación, donde todo, absolutamente todo, es materia de negaciación entre gente políticamente alineada, aunque esos alineamientos sean mutantes. Otro símbolo, en este caso metafórico, es el del tacho de agua lavandina : en él se remojan los informes de auditoría para lavarlos y desteñirlos, de modo que puedan ser aprobados por consenso (mínimo común denominador) en el Colegio de A uditores Generales, siete personas que cobran 10 mil pesas de sueldo, más gastos de movilidad y refrigerio, y manejan un presupuesto millonario con el que, por ejemplo, pueden tomar a 325 contratados y pasantes. A lgunos de éstos son estudiantes de historia del arte o psicologos, aunque no sean especialidades aptas para los menesteres del organismo. Pero nadie es quién para disautir un nombramiento porque la A GN está dividida en cotos de caza, y nadie pisa la quinta ajena" . (Pagina 12, 31/07/2004).

${ }^{18}$ A qualidade técnica dos informes não parece ser afetada pela politização (Santiso 2007b) 
credibilidade fica comprometida. É significativo que a instituição ainda não tenha uma Lei Orgânica definindo sua governança interna e regras de procedimento (Santiso 2007). Há, no entanto, modificações recentes que sinalizam melhorias no desempenho da AGN. Em primeiro lugar, os pareceres técnicos são disponibilizados na internet, permitindo assim uma mais efetiva accountability social, evitando-se a prática de engavetamento do trabalho de auditoria nas instâncias técnicas (Santiso 2007). ${ }^{19}$

No papel as atribuições da AGN são consistentes com o novo formato institucional adotado para a área e controle e reflete uma visão de controle cada vez mais advogada no plano internacional: uma instituição fortemente articulada com o Legislativo e com foco no controle a posteriori, avaliação de programas e auditoria operacional. O caso da AGN, no entanto, como assinala Santiso (2007), aponta para os limites existentes para o transplante de um modelo exógeno em um marco institucional mais amplo marcado por distorções e profundas vulnerabilidades.. O oportunismo político no timing de sua criação como também o seu novo formato repercutiu assim sobre a legitimidade da nova instituição. A debilidade da AGN sugere que o desempenho das instituições de controle é fortemente afetado pelo marco institucional mais amplo do país, em particular do conjunto das demais instituições de checks and balances. Se este último é instável e marcado por fortes problemas estruturais (Levistky e Murillo 2005; Spiller e Tommasi 2006)), o controle será igualmente afetado.

As demais instituições de controle externo do país - os tribunais de contas provinciais e municipais - apresentam um padrão bastante heterogêneo. Alguns tribunais não tem sequer webpage, enquanto um grupo bastante reduzido - do qual o tribunal da cidade autônoma de Buenos Ayres, é o exemplo mais destacado - são instituições bem aparelhadas. Em um estudo sobre os tribunais de contas das províncias de San Luis e Mendoza, Chavez (2004) mostra um quadro bastante contrastante. O tribunal de contas de Mendoza, instituído em 1931, historicamente mostrou-se muito mais efetivo e independente do que seu similar em San Luis. A composição do pleno destes tribunais é determinante de sua efetividade. Em Mendoza, onde historicamente tem havido forte competição política, o pleno reflete a alternância no poder entre as forças políticas rivais, radicais e justicialistas. Na década de 90 e final da década de 80 ,

${ }^{19}$ Estas mudanças levaram a um movimento pedindo o impeachment do presidente da AGN, Leandro Despouy, em 2006. Gonzalez de Rebella (2001) mostra também que mesmo antes destas modificações terem ocorrido, a imprensa repercutiu muitos informes não disponibilizados da AGN, permitindo amplo debate publico dos mesmos. 
dos sete membros do pleno (três dos quais são indicados pelos governadores), quatro haviam sido nomeados pela oposição justicialista, que assim controlava o tribunal. O pluralismo nas relações entre o executivo provincial e o tribunal garantiu um maior ativismo do controle (ibid., p. 131-132). Em contraste, em San Luis, observa-se forte hegemonia justicialista e o tribunal de contas se converteu em apêndice do grupo hegemônico comandado pelo governador Rodríguez Saá (ibid. 113-114).

\section{Chile}

O caso do Chile na América Latina exemplifica a adoção do modelo de General A uditor na região. ${ }^{20}$ Este modelo é aquele prevalecente nos países da antiga comunidade britânica das nações e dos EUA. Com efeito, desde sua criação na década de 20 do século passado a influência americana é clara na medida em que a Controladoria General de la Republica (CGR) foi modelada com base na sua congênere dos EUA, o General A coounting Office (GAO). No entanto o CGR tem traços peculiares e que lhes confere um perfil único. Alguns deles são comuns a outras contralorias da região como as do Peru e Bolívia cuja criação também decorreu da Kemmerer Mission.

Em primeiro lugar, a agência não mantém vinculação com o Legislativo, e desfruta de autonomia constitucionalmente garantida pelas sucessivas Constituições do país (1943, 1980). Assim a CGR tem o status de agência sem subordinação hierárquica, o que acontece em poucas agências no mundo, todas das quais em paises pouco institucionalizados do terceiro mundo. Em segundo lugar, a CGR preserva traços de corte de contas, o que lhes garante o exercício de poderes quase-judiciais. As atribuições da CGR foram definidas em lei orgânica (1952), emendada em 1964 e 2002. Isto confere a CGR um caráter híbrido - de corte de contas e de contraloria monocrática.

O mandato da CGR é amplo, embora mais restrito do que sua congênere argentina. São auditadas as contas e receitas do setor público nacional, inclusive dos entes sub-nacionais, concessionárias e empréstimos internacionais. No entanto, está fora de sua competência o julgamento de contas o Banco Central, o banco estatal e a maior empresa pública (a estatal de cobre). A CGR exerce o controle prévio de atos administrativos além do controle sucessivo, de

\footnotetext{
${ }^{20}$ Esta seção se baseia em Santiso (2007) e nas informações disponiveis no site da CGR, salvo quando indicado de outra forma.
} 
caráter estritamente de conformidade e legalidade. Parte importante de suas atribuições envolve atribuições típicas do executivo, como o controle dos registros relativos a recursos humanos, inclusive a custódia da declaração de bens de servidores, como estabelecido pela Lei de probidade administrativa de 1999. A CGR também supervisiona o sistema nacional de contabilidade pública, fixando regras contábeis, o que é inusitado para uma instituição de controle.

O orçamento do órgão atualmente não é fixado em lei, mas obedece prática institucionalizada pelo qual a CGR prepara seu plano de gastos e apresenta ao Ministério da Finanças. Entre 1959 e 1977, ele era estipulado como um percentual (0.32\%) do orçamento da Republica. Em 1978, o governo militar eliminou a prática de alocação de recursos em bases percentuais e alterou o regime salarial vigente. A intervenção culminou com a destituição do Presidente da CGR pelo governo Pinochet pela sua recusa em conceder visto prévio ao plebiscito organizado pela junta em 1978. Com a nomeação de um oficial do exército para presidir a instituição, o CGR passou a ser sido visto por alguns críticos como um enclave autoritário. Os governos de Lagos e Bachelet não intervieram nos mandatos dos dirigentes nomeados por seus antecessores mas lograram nomear dirigentes não comprometidos com ao regime militar. A despeito da instabilidade política no país nas ultimas décadas observa-se baixa turnover de auditor geral, o que sugere que o órgão manteve-se relativamente insulado da competição política mais ampla (Quadro 3).

\section{Quadro 3. CGR Mandatos dos Contralores Generales - 1927-2007}

\begin{tabular}{|c|c|}
\hline Pablo Ramírez Rodríguez & (Março 1927 - Julho 1927) \\
\hline Kenneth Page Oxley & (Julho 1927 - Dezembro 1927) \\
\hline Rodolfo Jaramillo Bruce ( & Janeiro 1928 - Janeiro 1929) \\
\hline Edicio Torreblanca White & (Janeiro 1929 - Novembro 1929) \\
\hline Miguel Solar Formas & (Novembro 1929 - Fevereiro 1932) \\
\hline Gustavo Ibáñez Rondizzoni & (Fevereiro 1932 - Dezembro 1938) \\
\hline Agustín Vigorena Rivera & (Janeiro 1939 - Dezembro 1945) \\
\hline Humberto Mewes Bruna & (Fevereiro 1946 - Junho 1952) \\
\hline Enrique Bahamonde Ruiz & (Setembro 1952 - Maio 1959) \\
\hline Enrique Silva Cimma & (Maio 1959 - Janeiro 1967) \\
\hline Héctor Humeres Magnan & (Agosto 1967 - Dezembro 1977) \\
\hline Sergio Fernández Fernández & (Dezembro 1977 - Abril 1978) \\
\hline Osvaldo Iturriaga Ruiz & (Abril $1978-1997)$ \\
\hline Arturo Aylwin Azocar & (1997 - Agosto 2002) \\
\hline$\overline{\text { Gustavo Schiolla }}$ & (Agosto 2002 - 2006) \\
\hline$\overline{\text { Ramiro Mendoza }}$ & (Abril 2007 -) \\
\hline
\end{tabular}

Fonte: ihttp: //www.contraloriagen. gov.co/html/home/home.asp 
O Auditor General é nomeado pelo Presidente da Republica, após confirmação pelo Senado da República, sendo o cargo vitalício até o limite de idade para aposentadoria compulsória no setor público aos 75 anos. A destituição do Auditor General do cargo que ocupa só pode ser feita após processo de impeachment iniciado pelo Senado. Como nos demais países que adotam o modelo institucional, há forte concentração de autoridade e responsabilidade na figura do A uditor General. O auditor chefe é responsável individualmente pelos pareceres da CGR. No plano organizacional ele também tem prerrogativas amplas, podendo recrutar e nomear funcionários, definir escalas salariais, entre outros. O último auditor geral nomeado - Sciolla Avendano - (pelo Presidente Lagos) era funcionário do órgão há 43 anos. Padrões meritocráticos de recrutamento, imagem externa de respeitabilidade e credibilidade, além de forte endogenia para os cargos de direcção na instituição e altos salários contribui para a formação de forte sprit de corps.

A CGR executa muitas atividades típicas de controle interno e de administração financeira. O órgão não audita os balancetes das contas publicas segundo as regras de auditagem aceitas internacionalmente pelas instituições multilaterais simplesmente porque ela própria os prepara (IMF 2003). A sobreposição do controle externo e interno significa que na pratica surgem muitas situações de conflito de interesse. A incorporação das atividades de controle interno pela CGR deve-se à atrofia dos mecanismos de controle interno, causada provavelmente pela própria expansão da CGR. Tais atividades absorvem grande parte dos recursos humanos da instituição e é consistente com o foco e missão histórica da instituição. Esta cultura enraizada do controle prévio e de administração financeira constitui um forte impedimento para que a instituição redirecione suas atividades para as atividades de controle sucessivo e, sobretudo de auditoria de desempenho, como tem sido o padrão internacional na área do controle externo contemporaneamente. Outro impedimento relevante é a competição inter-institucional resultante do fato de que o Ministério do Planejamento tem desenvolvido grande capacidade institucional na área de avaliação de programas e avaliação de desempenho.

A CGR também desempenha papel de corte de contas através de seu tribunal de Cuentas interno. Este tribunal se encarrega também do contencioso administrativo e pode impor multas, retenções de salários de agentes públicos ,e suas decisões só podem ser contestadas no âmbito da justiça, em segunda instância. O funcionamento do tribunal é peculiar. No juicio de auentas de um reparo contra agentes públicos ou ex-funcionários públicos 
visando a reparação de dano ao patrimônio, doloso ou por negligência, o tribunal cumpre o papel de julgamento de primeira instancia. "el juez de Primera Instancia es el Subcontralor, y el Tribunal de Segunda Instancia estará integrado por el Contralor General, quien lo presidirá, y por dos abogados que hayan destacado en la actividad profesional o universitaria, los auales serán designados por el Presidente de la República, a propuesta en terna del Contralor General.,21

A co-existência de funções de órgão normatizador da contabilidade nacional, registro de pessoal e tribunal de contas e outras funções de controle interno se explica pela fusão recomendada pela Kemmerer Mission (Drake 1989) de "la supresión de la Dirección General de Contabilidad, del Tribunal de Cuentas, de la Dirección General de Estadística y de la Inspección General de Bienes de la Nación",

A CGR realiza juicio de cuentas, emite dictamenes e tomas de razón e prepara, como órgão de contabilidade pública, o Balance Anual de la Gestión Financiera del Estado. Os dictamenes (pareceres) dispõe sobre petições de particulares ou funcionários sobre atos administrativos que lhes são lesivos. A interpretação do Tribunal é vinculante no âmbito da administração pública: "los didámenes de la Contraloría General conforman su jurisprudencia que es obligatoria para todos los órganos administrativos sometidos a su fiscalización. Los abogados de la A dministración deben atenerse a ella salvo cuando defiendan al Estado ante los Tribunales de Justicia".

A atividade controle prévio é realizada através da toma de razón - um instrumento jurídico importante do direito administrativo chileno. Com ele a CGR exerce o controle da legalidade e conformidade de atos administrativos. No entanto, "el Contralor General tiene atribuciones para eximir de dicho trámite a los decretos y resoluciones que incidan en materias que, a su juicio, no son esenciales" O prazo de emissão da toma de razon passou de 30 para 15 dias. Este instrumento que a CGR exerça um importante papel de veto player no sistema administrativo. No entanto, o executivo pode se sobrepor a toma de razón contraria interposta pela CGR através de um "decreto de insistência". O diagnóstico da CGR sugere que esta apresenta muitas características desejáveis para uma instituição de controle, tais como credibilidade, imparcialidade, profissionalismo e independência. No entanto é difícil estabelecer em que medida o sistema apresenta tais características devido à eficiência e forte institucionalidade presente no sistema estatal chileno ou a características intrínsecas à CGR. Dentre as características indesejáveis estão a falta de articulação com o Legislativo e o caráter obsoleto da

${ }^{21}$ Esta ação caduca no prazo de ano de instaurada. 
ênfase no controle prévio e no excessivo legalismo, formalismo e arcaísmo embutido no sistema de controle sucessivo.

\section{Brasil}

“....corpo de magistratura intermediária à Administração e à Legislatura que, colocado em posição autônoma, com atribuições de revisão e julgamento, cercado de garantias contra quaisquer ameaças, possa exercer suas funções vitais no organismo constitucional, sem risco de converter-se em instituição de ornato aparatoso e inútil...”

Rui Barbosa, Exposição de Motivos de criação do TCU,

O Tribunal de Contas da União (TCU) é uma instituição centenária: sua criação remonta à constituição de 1891. É um Tribunal singular sem congêneres no âmbito internacional. Ao contrário de algumas cortes de contas - como as de Portugal e Grécia - o Tribunal não é parte do poder judiciário, e sim do Legislativo. Suas decisões, portanto, não são vinculantes. No entanto, o TCU tem poderes quase-judiciais e exerce a função de tribunal administrativo, podendo emitir multas com caráter de título executivo, embargar a execução de licitações e obras, além de que seus julgamentos podem implicar em inelegibilidade de políticos envolvidos em ilícitos. Embora tais ações possam ser revogadas pelo Judiciário, essas prerrogativas conferem peso as decisões do tribunal.

O TCU tem status constitucional como órgão auxiliar do Congresso Nacional, que têm por missão realizar o controle externo dos diversos poderes. Atualmente sua jurisdição abrange todo o Território Nacional, estando sob seu alcance todo e qualquer cidadão que tenha sob sua guarda bens ou valores públicos da União ou que tenham dado prejuízo ao Erário Federal. O número de entidade sob jurisição do TCU tem se ampliado nos últimos anos e oscilado em termos de 2.500 entidades que são obrigadas a prestar contas, em um universo total de 6.000 jurisdicionados. Seu funcionamento também é regulado por Lei Orgânica e Regimento Interno. O Tribunal é composto por nove Ministros e três Auditores. ${ }^{22}$ Os Ministros são

22 A Constituição foi regulada pela Lei n. 8443/ 92 que detalhou as atribuições discriminadas na Constituição, ampliou o Ministério Público do Tribunal, alterou o processo de julgamento de contas (criou o julgamento de contas como regulares, regulares com ressalva, irregulares e iliquidáveis), e trouxe o cidadão como parte competente a apresentar denúncias ao Tribunal. 
indicados na proporção de 1/3 pelo Presidente da República (concorrendo a uma das três vagas os Auditores, Membros do Ministério Público e uma de livre escolha do Presidente) e 2/ 3 pelo Congresso Nacional (os quais se alternam na escolha a Câmara dos Deputados e o Senado Federal), e os Auditores são nomeados entre os aprovados em concurso público (as suas atribuições são de Ministros Substitutos). A natureza dos cargos de Ministros e Auditores é vitalício, só podendo ser nomeado para esses cargos brasileiros natos, maiores de 35 (trinta e cinco) anos e menores de 65 (sessenta e cinco) anos; idoneidade moral e reputação ilibada; notórios conhecimentos jurídicos, contábeis, econômicos e financeiros ou de administração pública e exercício por mais de 10 (dez) anos de função ou atividades que exijam os conhecimentos mencionados.

Como fiscal da lei no julgamento de processos de contas, existe trabalhando junto ao TCU o Ministério Público de Contas, independente do Ministério Público da União, que tem quadro próprio, composto de Procurador- Geral, três Subprocuradores - Gerais e quatro Procuradores. Esse Ministério- Público atua exclusivamente junto ao TCU, não ajuizando ações junto à Justiça Federal. A participação do Ministério Publico de Contas no TCU assegura um vinculo mais estreito com o Poder Judiciário.

A composição do TCU portanto é hibrida, combinando indicações do Legislativo, do Executivo, este último restrito a uma livre nomeação, e representação de quadros concursados da própria burocracia pública. Este perfil não existe em outras corte de contas, e juntamente com o instituto da vitaliciedade contribui para reduzir a politicização resultante da sua subordinação ao legislativo e o papel que este último tem nas nomeações dos demais membros. No entanto, a independência do TCU é muito menos expressiva do que nos seus congêneres em que o acesso aos cargos superiores obedece às mesmas regras do Judiciário.

O TCU exerce um número amplo de funções. fiscalizadora, judicante, normativa, consultiva, e de ouvidoria. Ao órgão cabe julgar as contas dos administradores (de unidades dos Poderes da União e administração indireta federal), e as contas de responsáveis por danos ao Erário; proceder por iniciativa própria ou solicitação do Congresso Nacional à fiscalização contábil, financeira, patrimonial e orçamentária das unidades dos Poderes da União; emitir parecer nas contas prestadas anualmente pelo Presidente da República; acompanhar a arrecadação da receita a cargo da União; apreciar, para fins de registro, a legalidade de atos de admissão, aposentadoria e pensão dos servidores dos Poderes da União; efetuar os cálculos das 
quotas relativas as transferências constitucionais aos estados e municípios ( FPE e FPM); alem de decidir sobre denúncias de terceiros.

O TCU tem a missão ainda de acompanhar a Gestão Fiscal. Com a promulgação da Lei de Responsabilidade Fiscal, a Lei Complementar n. ${ }^{\circ}$ 101/ 00, e a legislação complementar que criminalizou uma série de procedimentos, com a Lei n. ${ }^{\circ}$ 10.028/00, O TCU e demais tribunais subnacionais, tiveram sua responsabilidade ampliada para incluir o cumprimento da responsabilização fiscal. ${ }^{23} \mathrm{O}$ TCU passou também por dispositivos seguidamente incluídos nas Leis de Diretrizes Orçamentárias desde $1997^{24}$ a preparar a listagem das obras com indícios de irregularidades. (Ribeiro 2004). O modelo de accountability é assim duplo. As contas do governo são de responsabilidade do Presidente da República, e o juízo político sobre crimes de responsabilidade cabe ao Senado. No plano dos gestores, a responsabilização recai sobre o ordenador de despesa diretamente e à Justiça cabe sua responsabilização criminal.

A constituição ampliou o mandato do TCU ao fixar novos parâmetros para o controle. O controle deve englobar a apreciação contábil, patrimonial, orçamentária e operacional e se pautar pelos requisitos de "legitimidade, legalidade e economicidade" . Esta mudanças abriram o caminho para que o TCU pudesse exercer o controle também da efetividade de projetos e programas através de auditoria de desempenho. No entanto, sua atuação nesta área ainda é tímida. O tipo de controle exercido pelo TCU é de natureza prévia (ainda que bastante limitada), concomitante e sucessiva, e voltado fundamentalmente para o controle de legalidade. A Constituição também inovou ao incluir as receitas na atividade de controle a ao estipular que as multas imputadas tenham caráter executivo. No entanto, este último dispositivo nunca teve efetividade plena.

\footnotetext{
23 A Lei de Responsabilidade Fiscal criou a obrigatoriedade da elaboração e publicação bimestral do Relatório Resumido da Execução Orçamentária e, quadrimestralmente, do Relatório de Gestão Fiscal, bem como a sua divulgação pela rede mundial de computadores. A Lei de Responsabilidade Fiscal, complementada pela Lei de Crimes Fiscais, criou um regime bastante restritivo para o último ano de exercício do mandato dos chefes de poderes vedando o aumento de despesas com pessoal no último semestre do mandato; e estipulando que a inscrição de despesas relativas aos últimos oito meses de mandato em Restos a Pagar só pode ser efetuada com a respectiva cobertura financeira.
}

${ }^{24}$ Neste ano, em virtude do chamado escândalo do orçamento, passou-se a exigir a listagem das obras com indícios de irregularidades. 
O visto prévio de contratos e admissões/ pensão de servidores, existente até a constituição de 1946 foi sendo progressivamente abandonado, até chegar a representar apenas 5\% dos atos em 1960 (Ribeiro 2002). A constituição de 1967 eliminou de vez o visto prévio. O TCU emite relatórios trimestrais, que são consolidados anualmente, prestando contas de suas atividades ao Congresso Nacional. Estes relatórios, no entanto, tem um caráter meramente quantitativo, incluindo poucos dados qualitativos, o que impede uma avaliação mais profunda das dimensões da eficácia e efetividade das atividades desenvolvidas pelo Controle.

O TCU também prepara um parecer prévio as contas do Governo. Esta atividade de responsabilização política é realizada pelo Congresso Nacional. No entanto, o TCU tem sempre apreciado de forma favorável as contas do governo. Esta apreciação deixa muito a desejar, e o padrão geral tem sido de não apreciação ao invés de não-aprovação. Isto aconteceu em relação as contas dos governos Collor e Lula - quando houve notórios caso de corrupção. (cf Tabela 6). Historicamente, o Brasil negligenciou esta obrigação. O TCU tem emitido pareceres favoráveis a todas as contas presidenciais, desde 1946, e o Congresso Nacional sempre dilatou o prazo de julgamento (Pontes e Pederiva 2004; Pessanha 2007). No entanto há diferenças gritantes entre o caso brasileiro e argentino, onde no último caso esta negligência assumiu a forma de total descontrole. Todas as contas apresentadas a partir de 1988 foram apreciadas dentro do prazo constitucional estabelecido e, invariavelmente, aprovadas pelo Tribunal, embora algumas com "ressalvas" e/ ou "recomendações" (Pessanha (2007)

Como assinala Pessanha (2007, p. 20):

“é incrível o lapso de tempo entre a apreciação pelo Tribunal e o julgamento pelo Congresso. As contas de Itamar Franco, relativas ao ano de 1993, foram julgadas pelo Congresso nove anos depois. Das oito prestações de contas de Fernando Henrique Cardoso, seis foram aprovadas no mesmo dia ao final do seu governo, em 20 de dezembro de 2002, e as relativas ao último ano, em fevereiro de 2003; (C) as contas de Luiz Inácio Lula da Silva de 2003, 2004 e 2005, também aprovadas pelo Tribunal dentro dos prazos constitucionais previstos, ainda não foram julgadas pelo Poder Legislativo; e (d) Fernando Henrique Cardoso e Luiz Inácio Lula da Silva apresentaram-se aos eleitores para reeleição em 1998 e 2002, respectivamente, sem que nenhuma das suas contas do primeiro mandato tivessem sido julgadas pelo Legislativo; 
em outras palavras, os eleitores votaram desconhecendo uma análise pública do desempenho de ambos os presidentes “

Contando com cerca de $0.5 \%$ do orçamento federal, o TCU tem um aparato administrativo robusto e grande capacitação técnica. $\mathrm{O}$ principal risco que a instituição tem enfrentado nas últimas duas décadas, é de tornar-se um “ornato aparatoso e inútil", para utilizar a expressão de Rui Barbosa. Ou de um tigre sem dentes, como sugere Torgler (2005) para os Tribunais de Contas cantonais suíços. Isto se deve fundamentalmente à falta de efetividade do trabalho de controle exercido pelo Tribunal. No Plano macro, o Tribunal sujeita-se à responsabilização política - ou falta dela - exercida pelo Legislativo. No plano da responsabilização de contas de gestores o TCU esbarra no fato de que suas decisões não são vinculantes. Os gestores e agentes políticos podem recorrer das decisões do TCU na Justiça Comum. Os dispositivos da Constituição que procuraram dotar o Tribunal de algum poder vinculante - como a imputação de débitos com eficácia de titulo executivo - não tem sido efetivados na prática por resistência do Judiciário ao processo gradativo de judicialização do controle externo (Rocha 2006). 


\section{Tabela 6.}

\section{Tramitação das Contas de Gestão do Governo da República Federativa do Brasil}

\begin{tabular}{|c|c|c|c|}
\hline Contas de Gestão & Governo & Tribunal Contas & Congresso Nacional \\
\hline 1988 & Sarney & Aprovada 06.89 & Aprovada 05.91 \\
\hline 1989 & Sarney & Aprovada 05.90 & Aprovada 05.92 \\
\hline 1990 & Collor (1) & Aprovada 06.91 & (2) \\
\hline 1991 & Collor & Aprovada 06.92 & (2) \\
\hline 1992 & Collor(3) & Aprovada 06.93 & (2) \\
\hline 1993 & Itamar & Aprov.Rec. 06.94 & Aprovada 12.02 \\
\hline 1994 & Itamar & Aprov.Res. 06.95 & Aprovada 12.96 \\
\hline 1995 & FHC & Aprov.Res.05.96 & Aprovada 12.02 \\
\hline 1996 & $\mathrm{FHC}$ & Aprovada 06.97 & Aprov.rec. 12.02 \\
\hline 1997 & FHC & Aprovada 06.98 & Aprovada 12.02 \\
\hline 1998 & $\mathrm{FHC}$ & Aprov.Res. 06.99 & Aprovada 12.02 \\
\hline 1999 & FHC & Aprov.Rec. 06.00 & Aprov.res. 02.03 \\
\hline 2000 & FHC & Aprov.Res. 06.01 & Aprovada 12.02 \\
\hline 2001 & FHC & Aprov.Resc. 06.02 & Aprovada $\quad 12.02$ \\
\hline 2002 & FHC & Aprov.Resc. 06.03 & Aprovada $\quad 02.04$ \\
\hline 2003 & Lula & Aprov.Rec. 06.04 & (2) \\
\hline 2004 & Lula & Aprovada $\quad 06.05$ & (2) \\
\hline 2005 & Lula & Aprov.Res. 06.06 & (2) \\
\hline
\end{tabular}

Fonte: Secretaria de Contas do Governo e Transferências Constitucionais - SECON, TCU. Obs.: (1) Inclui período de $1^{\circ}$ de janeiro a 15 de março do Governo Sarney.

(2) Contas não apreciadas até 31.12.06.

(3) Itamar Franco assumiu provisoriamente a partir de 2/9 e, definitivamente, a partir de 27.12.

Fonte: Pessanha 2007 
Na prática, a resistência aposta pela Judiciário tem sido extremamente eficiente, e as condenações do Tribunal, inclusive no que se refere à penalidades previstas pela legislação, tais como inelegibilidade por período de 8 anos, tem enorme dificuldade de serem enforced devido a possibilidade de sucessivos recursos pelos indiciados.

O segundo tipo de fator determinante da inefetividade dos tribunais de contas - em vários níveis - tem sido a ênfase colocada em controle de regularidade e conformidade, de natureza exclusivamente legal, ao invés de foco em auditoria física e inspeções in loco. Por um mecanismo extremamente perverso, este padrão de atuação dos TCs tem se constituído em mecanismo bastante efetivo de desresponsabilização. Isto ocorre pela prática corrente por parte de agentes públicos implicados em situações de corrupção de alegarem de que "o Tribunal não achou nada que desabone sua conduta", tendo em vista que controle de perfil legalista não dá conta de verificar irregularidades. Os TCs passam então a se constituir em instituição que confere atestados de probidade a agentes públicos corruptos.O único impacto claramente discernível do Tribunal tem sido na sua capacidade de embargar obras e licitações. O TC dispõe assim de um poder negativo. ${ }^{25}$

\section{Falhas da Accountability horizontal: deficiência da accountability vertical ou do} rule of law?

As lições a serem extraídas dos casos sumarizados nas seções anteriores sugerem que a efetividade do controle depende menos do modelo institucional do que da estrutura institucional mais ampla do país. Esse achado é consistente com as conclusões de Blume e Voigt (2007) e Santiso (2007). O primeiro em análise cross section - utilizando-se de uma amostra significativa de países $(n=53)$, que inclui o Brazil, Argentina e Chile - conclui que o modelo institucional da SAI tem pouca influência nos resultados econômicos em geral

\footnotetext{
${ }^{25}$ Como assinala Rocha (2004) dois dispositivos combinados definem este poder negativo: o dispositivo Constitucional que atribui ao Congresso Nacional, e subsidiariamente ao Tribunal de Contas da União, a capacidade de anular contratos; e o dispositivo da Lei de Responsabilidade Fiscal (LC 101/ 00) que determina que o Orçamento só pode iniciar obra nova se as que estão em andamento receberam recursos suficientes para sua continuidade
} 
(comportamento fiscal, produtividade total de fatores) ${ }^{26}$, mas autores observaram uma correlação, no entanto, entre percepção da corrupção e utilização do modelo tribunal de contas. destes autores A explicação encontrada pelos autores é que:

"One plausible explanation is the relative lack of parliamentary involvement in the auditing process under the court model. The relative seclusion of the process makes it less transparent for the public, its results will often not lead to public outcry, and the expected utility of being corrupt is high as the likelihood or being sanctioned by a furious public is correspondingly low” (Blume and Voigt 2007, 20).

Segundo este argumento, mesmo que o Legislativo não acione dispositivos de responsabilização para os desvios de conduta - como acontece nos casos de parlamentos pouco ativos ou controlados pelo executivo - a visibilidade destes atos seria provavelmente maior nos casos dos modelos de tribunais do que nos modelos de auditor geral. Esta maior visibilidade aumentaria o custo político para os agentes públicos, que por sua vez, internalizariam as futuras sanções pela via eleitoral pelos cidadãos, abstendo-se da prática de atos corruptos. Este argumento é parcialmente aplicável ao caso brasileiro devido ao fato de que apenas quando as auditorias dos tribunais adquirem visibilidade - a partir da repercussão de casos na mídia - é que se observa desdobramentos da ação de controle (mobilização do Ministério Público e ou a convocação de autoridades, formação de CPI, etc.). Ou seja, mesmo no casos de paises que adotam o modelo de Tribunais, se houver publicização do trabalho de controle através de mecanismos de alarme de incêndio, observa-se maior probabilidade de desdobramentos, e internalização dos custos pelos agentes políticos. O mesmo acontece na Argentina, em contraste, por exemplo, com o caso chileno, onde mesmo se adotando o modelo de auditor, os relatórios da CGR têm baixa visibilidade. Para os casos de Brasil, Chile e Argentina, a forte variação observada no desempenho do controle externo sugere que outras variáveis importam.

Para que esta questão seja adequadamente discutida, é necessário estabelecer uma distinção entre: a) responsabilização institucional de individual de agentes políticos envolvidos

\footnotetext{
${ }^{26}$ Na realidade, há poucas razões para se esperar uma associação entre eficiência, produtividade ou comportamento fiscal, como tais autores argumentam. Como vimos, muitas SAIS exercem apenas controle de compliance (regularidade formal) de natureza legal, não sendo razoável esperar que tal controle impacte as constas públicas. Afinal, um governo pode estabelecer metas fiscais expansionistas, que produzam déficits, sem que estejam fora da lei. Mesmo para as SAIS que exercem controle de performance, esta tendência é recente e surgiu em virtude da influência do chamado New Public Management na década de 90.
} 
em ilícitos através do controle externo e pela via judicial e b) a responsabilização vertical via processo eleitoral das repercussões das ações de controle. A figura 5 ilustra estas duas formas de responsabilização, as quais podem estar presentes simultaneamente ou não. A célula 1 representa o caso virtuoso de responsabilização política e judicial, ou seja, quando a responsabilização institucional tem repercussões eleitorais e vice-versa. A célula 2, por sua vez, representa os casos em que um processo de responsabilização não tem repercussões eleitorais. Constitui o cenário "rouba mais faz", no qual governantes podem ser objeto de sanção, mas sem que estas últimas acarretem custos políticos significativos. As células 3 e 4 representam casos de controles horizontais escassos ou débeis, podendo ou não haver custos eleitorais para os agentes políticos. Quando os controles são débeis resta apenas a sanção política pelos cidadãos. A célula 4 representa os casos em que esta última falha. $\mathrm{O}$ argumento de Moreno, Crisp e Shugart é essencialmente que a célula 2 representa uma impossibilidade lógica porque essencialmente a qualidade da responsabilização é determinada pela accountability horizontal. Do ponto de vista dinâmico o argumento implicaria na deterioração gradativa da qualidade do controle (indicado pela seta ligando as células 2 e 4). Da mesma forma, segundo estes autores, a célula 3 não é prevista pelas mesmas razões, e se espera que a conexão eleitoral alimente um ciclo virtuoso de aperfeiçoamento do controle. Este ciclo estaria representado pela seta ligando as células 4 e 1 .

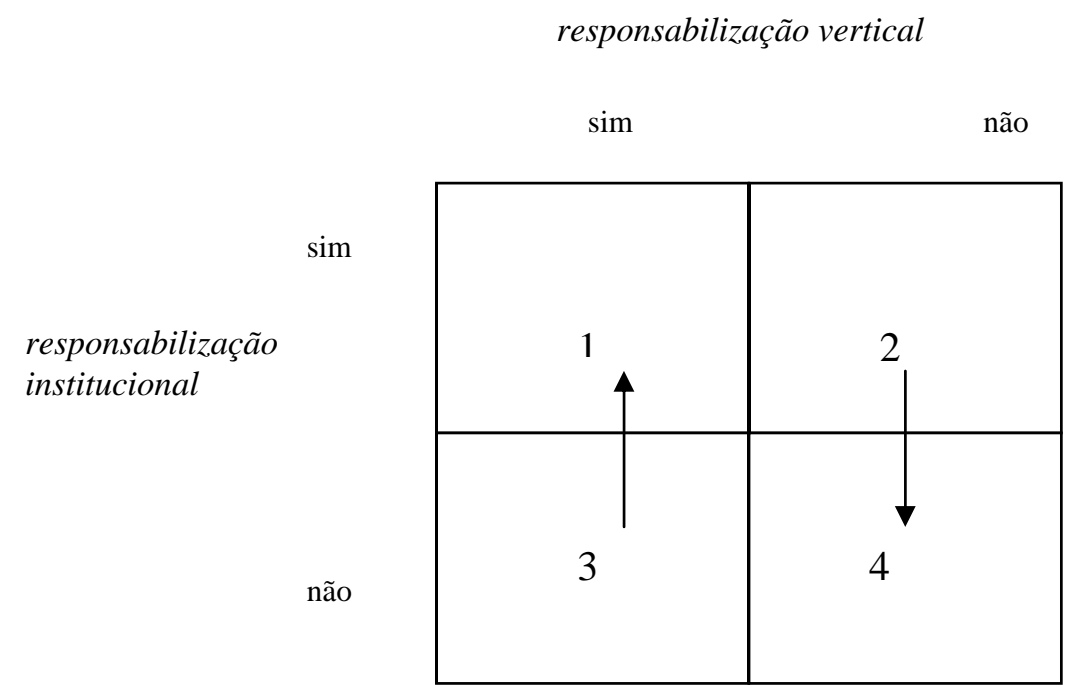

Figura 5. Interface entre responsabilização institucional e responsabilização vertical 
A responsabilização vertical está associada aos custos políticos mais amplos que a ação de controle acarreta, A publicização das ações de controle podem importar em ônus político, embora possa não produzir a responsabilização individual de agentes (nem ressarcimento ao erário de danos ao patrimônio público). Neste sentido, a questão essencial é: porque as ações de controle tem baixa efetividade em termos de responsabilização nas esferas administrativa e penal? Muitas das variáveis relevantes para a explicação são as mesmas que são relevantes para a explicação das razões da baixa efetividade do judiciário:

i. baixa capacidade institucional e organizacional do judiciário

ii. lentidão processual em um quadro de prescrição precoce de crimes (salvo danos ao erário que são imprescritíveis)

iii. excesso de instâncias recursivas,

iv. problemas de instrução processual,

v. exigências formais excessivas (verdade probatória)

vi. corrupção no judiciário

vii. controle político do judiciário

No caso dos TCs brasileiros há o problema de incompatibilidade de incentivos, porque em adição ao problema dos questionamentos em torno da imputabilidade de multas com características de titulo executivo, o enforcement das penas pecuniárias depende da inscrição do débito em dívida ativa da unidade federativa relevante pela procuradoria correspondente para execução judicial, cuja titular é nomeado pelo executivo. Neste sentido cabe a procuradoria municipal, que é nomeada pelo executivo municipal, inscrever na divida ativa do município a multa e executá-la. O mesmo se aplica a procuradoria da Fazenda Nacional. ${ }^{27}$ Este arranjo institucional no caso brasileiro é fonte importante de impunidade.

Há uma classe especial de sanções que são de natureza inteiramente jurídica - os juízos de responsabilidade. Neste caso, a efetividade da sanção pouco tem a ver com os problemas

\footnotetext{
${ }^{27}$ A tendência da interpretação tem sido no sentido de garantir a execução independente de inscrição de divida ativa, mas a própria querela enseja protelações. Para Calmon "s plenitude das normas constitucionais já indica que o Tribunal de Contas pode aplicar a sanção pecuniária e cobrá-la imediatamente, sob pena de ter-se uma grande ironia, porque ficaria ele a reboque do órgão do Ministério da Fazenda, por ele fiscalizado. Observe-se que cabe ao Tribunal de Contas aplicar a sanção pecuniária ao administrador faltoso, inclusive ao procurador da Fazenda, a quem incumbe fazer a inscrição. Hoje, o entendimento majoritário é no sentido de que se trata de título executivo por imposição constitucional (art. 71, §3) " (Calmon 2003, p. 12).
} 
mencionados. Trata-se do controle exercido por agentes políticos frente aos ilícitos cometidos por outros agentes políticos. Estes são os casos de entre outros impeachment e cassação de mandato. Neste caso, a estrutura de incentivos criada pela lógica política- partidária é determinante porque o Judiciário não está envolvido. Outro caso semelhante ocorre nos casos em que há a necessidade de licença legislativa prévia para se processar parlamentares envolvidos em crimes, inclusive comuns.

A segunda questão remete aos custos políticos nos casos de não-punição pela via judicial, cível e administrativa ${ }^{28}$ A responsabilização neste caso restringe-se às sanções que os cidadãos podem impor através do voto ou pela mobilização social. Esta última no entanto está sujeita a fluxos erráticos e representa um substituto imperfeito para a responsabilização vertical. Embora nos casos do Brasil e Argentina, observa-se uma maior efetividade do controle quando há forte mobilização e intensa cobertura mediática, a accountability social é um second best que produz respostas de curto prazo e ocasionalmente inovaç

O fator determinante para a efetividade do controle são os incentivos produzidos pela conexão eleitoral, uma vê que em ultima instância são os executivos que nomeiam e os legislativos que aprovam os titulares das agências de controle. Na realidade a própria independência de agências autônomas (como os ombudsman, instituições judiciais e parajudiciais) tem sido pensada essencialmente como um sub-produto da competição eleitoral (Chavez 2004; Finkel 2004).

Se os partidos políticos são escassamente institucionalizados e o sistema de representação fragmentado, a capacidade dos cidadãos de exercer controle sobre os governantes, punindo-os ou recompensando-os pelo desempenho, será consequentemente baixa. Nos sistemas presidencialistas a capacidade de responsabilização é maior porque, devido a separação de poderes, há maior incentivo para o controle recíproco entre os poderes. Como assinala Ostrom, nestes sistemas há maior potencial para a redução do risco moral (moral hazard) embora a custo de menor capacidade de resolução de problemas de seleção adversa (adverse selection). Quando os partidos são fortes e o label partidário pesa na competição política - como nos sistemas parlamentaristas -, os custos políticos associados a desvios de conduta de parlamentares afetam todos os membros do partido, o que gera incentivos para as lideranças

\footnotetext{
${ }^{28}$ A esfera cível refere-se aos danos ao erário; a esfera penal aos crimes que podem ter sido cometidos e finalmente a esfera administrativa corresponde aos julgamentos realizados no âmbito dos tribunais os quais podem acarretar inelegibilidade ou penas pecuniárias.
} 
exercerem maior controle sobre o recrutamento dos seus membros. No entanto, quando há forte fragmentação do sistema partidário e as coalizões de governo se formam em contexto pós-eleitoral, a clareza de responsabilidade no sistema diminui e a capacidade de responsabilização consequentemente diminui.

No contexto latino-americano, duas alternativas são possíveis para o fortalecimento do controle externo. Em primeiro lugar, reformas institucionais voltadas para eliminar as patologias do sistema de representação. Esta representaria a agenda maximalista de reforma, e no curto prazo, de improvável implementação. Na ausência de partidos programáticos, os agentes políticos que fazem parte de seus órgãos de deliberação superior têm fortes incentivos para se engajar em conluios de natureza clientelista. Nos poucos estados brasileiros em que há pluralismo no pleno dos TCEs e há competição política programática, a qaulidade do controle é melhor.

$\mathrm{Na}$ ausência de tais reformas, a segunda alternativa seria garantir a independência e autonomia das instituições de controle. No caso brasileiro, Isto significaria que o TCU e TCs se tornassem independentes, adotando-se um formato institucional semelhante, em termos de autonomia, aos do Ministério Público. Seu órgão de deliberação deveria ser recrutado de um pool de auditores concursados a serem escolhidos em lista tríplice pelos executivos, ouvido as câmaras legislativas. Suprimir-se-iam, portanto, os membros designados pelo Legislativo e pelo Executivo. Os detalhes desta formatação são pouco relevantes tendo em vista a eliminação da principal causa de distorção nessas instituições, o hiato entre o ativismo do seu corpo funcional técnico nas auditorias e as práticas de juízos político-partidários nos julgamentos de contas de gestores e do executivo.

\section{Referências}

Alves, Eliana Calmon. (2003) A Decisão Judicial e a Decisão do Tribunal de Contas: independência das instâncias administrativas, cível e penal. Revista Ibero-A mericana de Direito Público, v.4, n.11.

Arantes, R.B; Abrucio, F.L.; Teixeira, A. A. C. (2005) "A Imagem dos Tribunais de Contas Subnacionais”, Revista do Serviço Público, Vol. 56, n. 1, Jan-mar, pp. 57-83. 
Blume, Lorenz e Voigt, S (2007) Supreme Audit Institutions: extremely superfluous? a cross country assessment, paper a ser apresentado na XII Conferencia da ISNIE, Reikjavik, 19-21 Junho.

Bugarin, Maurício S; Vieira, Laércio M; Garcia, Leice M. (2003) Controle dos Gastos Públicos no Brasil: instituições oficiais, controle social e um mecanismo para ampliar o envolvimento da sociedade. Rio de Janeiro: Konrad Adenauer Press.

Carol, R. \& Shugart, M. (2006), "Neo-madisonian theory and Latin American institutions". Working paper 03-06, Center for the Study of Democracy, University of California, Irvine.

Chavez, Rebecca (2004) The rule of law in nascent democracies: judicial politics in A rgentina, Stanford University Press.

Despouy, L., et al. (2002). El control público en la Argentina (Buenos Aires: AGN).

Dove, S. (2002) Fragile Miracles: The Creation and Sustainability of Autonomous Oversight Agencies in a Politicized Bureaucracy: The Case of Bolivia (Barcelona, Spain: Universidad Autónoma de Barcelona, unpublished doctoral dissertation).

Drake, P. (1989). The Money Doctor in the Andes: The Kemmerer Missions, 1923-1933 (Durham: Duke University Press).

Dye, K., and R. Stapenhurst (1998). Pillars of Integrity: The Importance of Supreme Audit Institutions in Curbing Corruption (Washington, DC: WBI).

Feld, L. and S. Voigt (2003); Economic Growth and Judicial Independence: CrossCountry Evidence using a new set of indicators, European Journal of Political Economy: 19(3), 497527.

Fernandes, Jorge Jacoby (2003) Tribunais de contas do Brasil: Jurisdição e competência, Belo Horizonte, Fórum.

Fiedler, Franz (2004) “The independence of audit institutions”, in INTOSA I 50 years 1952-2003, Oslo

Finkel, Jodi (2004) "Judicial reform in Argentina in the 1990s: how electoral incentives shape institutional change," Latin American Research Review, 39 (3): 56-80.

Freedom House (2000); Press Freedom Survey 2000, downloadable from: hittp://freedomhouse.org/pfs $2000 /$ method.htm

Frey. B.S. (1994): Supreme Auditing Institutions: A Politico-Economic Analysis. European Journal of Law and Economics. Vol 1 (1): 169-76. 
Figueiredo, A. (2003). 'The Role of Congress as an Agency of Horizontal Accountability: Lessons from the Brazilian Experience,' in S. Mainwaring and C. Welna, eds. Democratic Accountability in Latin America, 170-198.

Figueiredo, Carlos, Melo, Marcus and Pereira, Carlos (2006) The corruption-enhancing role of reelection incentives? evidence from audit reports in Brazil", paper presented at the 9th Annual Conference of the International Society for New Institutional Economics (ISNIE), Boulder, Colorado, 21-23 September.

González de Rebella, L.C. (2001). El control externo del sector público: la Auditoría General de la Nación, paper presented at CLAD VI International Congress, Buenos Aires, Argentina, 5-9 November.

Kaufmann, D., A. Kraay, and M. Mastruzzi (2003). "Governance Matters III: Governance Indicators for 1996-2002". World Bank Policy Research Department Working Paper. Levistky, Steven and Murillo, Maria Victoria (2005) A rgentine democracy: the politics of institutional weakness, Penn State University Press.

IMF (2003). Chile: Report on the Observance of Standards and Codes - Fiscal Transparency, 03/237 (Washington, DC: IMF).

INTOSAI (1977) The Lima Declaration of Guidelines on Auditing Precepts issued by the International Organisation of Supreme Audit, [1998].

Llanos Campos, P. (2003). Antecedentes institucionales de la Contraloría General de la República de Chile (Santiago: CGR).

Morgenstern, S., and L. Manzetti (2003). 'Legislative Oversight: Interests and Institutions in the United States and Argentina,' in S. Mainwaring and C. Welna, eds. Democratic Accountability in Latin America, op.cit., 132-169.

National Audit Office (2005) State Audit in the European Union, London;

Dfid (2004) Characteristic of different external audit systems, London, Briefing; Strom, K. (1990), Minority government and majority rule. Cambridge/Nova York, Cambridge University Press. . (2000), "Parties at the core of government", in R. J. Dalton e M. P. Wattenberg (eds.), Parties without partisans: political change in advanced industrial democracies, Oxford/Nova York: Oxford University Press. . (2003), "Parliamentary democracy and delegation", in K. Strom, W. Miller e T. Bergman (eds.), Delegation and accountability in parliamentary democracies, Oxford/ Nova York, Oxford University Press. 
Przeworski, A.; Stokes, S. C. \& Manin, B. (eds.). (1999), Democracy, accountability, and representation. Cambridge/Nova York, Cambridge University

Przeworski, A. (2001), "Accountability social en America Latina y mas alla", in E. Peruzzotti e C. Smulovitz (eds.), Controlando la política: audadanos y medios en las nuevas democracias latino americanas. Buenos Aires, Temas Grupo Editorial. Press.

Powell, G Bingham___ (2005), “The chain of responsiveness”, in L. Diamond e L. Morlino, Assessing the quality of democracy, Baltimore, The Johns Hopkins University Press.

McCubbins, M. D. \& Schwartz, T. (1984), “Congressional oversight overlooked: police patrol versus fire alarm”. American Journal of Political Science, 28 (2): 165-179.

Melo, Marcus, Figueiredo, Carlos and Pereira, Carlos (2006) "Political and electoral uncertainty enhances accountability! A comparison of the independent courts of accounts in Brazil", paper presented at the 9th Annual Conference of the International Society for New Institutional Economics (ISNIE), Barcelona 22-24 2005.

Moreno, E.; Crisp, B. \& Shugart, M. D. (2003), "The accountability deficit in Latin America", in S. Mainwaring e W. Christopher (eds.), Democratic accountability in Latin America. Oxford/Nova York, Oxford University Press.

National Audit Office (2005) State Audit in the European Union, London; Dfid (2004) Characteristics of different external audit systems, London, Briefing;

O’donnell, G.; Cullell, J. V. \& Iazzetta, O. (2004), The quality of democracy: theory and applications. South Ben, University of Notre Dame Press.

O'donnell, G (1998), "Horizontal accountability and new poliarchies", in A Schedler et al, The self-restraining state: power and accountability in new democracies, Lynne Rienner.

OECD/Weltbank (2003): „OECD/WB Budget Practices and Procedures Survey“. Downloaded frominttp://ocde.dyndns.orgh.

OECD (1996) The Audit of Secret and Politically Sensitive Subjects: Comparative Audit Practices. Sigma Papers: No. 7. Paris.

Pessanha, C. (2003). 'O Congresso Externo sob Controle das Contas do Tribunal Nacional,' Inteligência 21:120-129

(1999). O Controle externo do Legislativo sobre o Executivo no Brasil: 1946-1998 (unpublished manuscript). 
Petrei, H. (1998). Budget and Control: Reforming the Public Sector in Latin America (Washington, DC: IDB).

Pontes, J.B., and J.H. Pederiva (2004). Contas Prestadas pelo Presidente da República: Apreciação do Congresso Nacional (Brasilia: Consultoria Legislativa do Senado Federal, Textos para a Discussão 14).

Ribeiro, R. B. (2002a). O Controle Extemo Federal no Brasil. (Rio de Janeiro: Fundação Getúlio Vargas). (2002b). Controle Externo da Administração Pública Federal no Brasil: O TCU _ Uma Análisis Jurídico-administrativa (Rio de Janeiro: América Jurídica).

49

Ribeiro, Renato B (2004) Os mecanismos de controle de contratos e obras públicas inseridos no orçamento brasileiro, IX Congreso Internacional del CLAD sobre la Reforma del Estado y de la Administración Pública, Madrid, España, 2 - 5 Nov.

Rocha, A. (2003). 'Especialização e Autonomia Funcional no Âmbito to Tribunal de Contas da União,' Revista de Informação Legislativa 40(157):223-251.

(2006) O Tribunal de Contas da União, in Mendes, Marcos (ed) Gasto Publico eficiente: 91 propostas para o desenvolvimento do Brasil, São Paulo, Topbooks/Instituto Braudel.

Rodríguez, J., and A. Bonvecchi (2006). El papel del poder legislativo en el control presupuestario: La experiencia argentina en perspectiva comparada (Santiago: CEPAL Working Paper 51).

Rodríguez, J., and A. Bonavicchi (2004). El papel del poder legislativo en el proceso presupuestario: la experiencia argentina (Santiago: ECLAC Working Paper 32).

Santiso, Carlos2007. "Auditing for Accountability" The Political Economy of Government Auditing and Budget Oversight in Emerging Economies. Washington, DC: Johns Hopkins University, unpublished doctoral dissertation

206a 'El día que me quieras: Parlamentos y presupuestos en América Latina,' Braun, Miguel, Luciana Diaz Frers and Gerardo Uña, eds. Cada cual; ¿atiende su juego? El rol del Congreso en el Presupuesto Nacional de Argentina (Buenos Aires: CIPPEC).

2005 Budget Institutions and Fiscal Responsibility: Parliaments and the Political Economy of the Budget Process (Washington, DC: WBI Working Paper No. 37253). 
2004. Legislatures and Budget Oversight in Latin America: Strengthening Public Finance Accountability in Emerging Economies,' OECD Journal on Budgeting 4(2):4777.

2006 b Eyes Wide Shut: Autonomous Audit Agencies in Emerging Economies, unpublished manuscript.

2006c "Improving fiscal governance and curbingcorruption: how relevant are autonomous audit agencies", International Public Management Review, Vol, issue 2.

Siavelis, P. (2002). 'Disconnected Fire Alarms and Ineffective Police Patrols: Legislative Oversight in Postauthoritarian Chile,' Journal of Interamerican Studies and World Affairs 42(1):71-98.

Schelker, M. and R. Eichenberger (2004): Independent and Competing Institutions: An Effective Way to Control Government, Paper presented at the annual meeting of ISNIE, Tuscon, Arizona, August. 30

Stapenhurst, R./ Titsworth. J. (2001): Features and functions of supreme audit institutions. World Bank, $\quad$ PREMnote [ihttp://WwW1.Worldbank.org/prem/PREMNotes/premnote59.pdf].

Streim, H. (1994): Agency Problems in the Legal Political System and Supreme Audit Institutions. European Journal of Law and Economics. 1 (1):177-91.

Strom, K., Miller, W. and Bergman, T. (eds), Delegation and accountability in parliamentary democracies. Oxford and New York: Oxford University Press, 2003.

Speck, Bruno Wilhelm (2000) Inovação e rotina no Tribunal de Contas da União: o papel da instituição superior de controle financeiro no sistema político-administrativo do Brasil. São Paulo: Konrad Adenauer Press.

-----------(2001). “Avaliação institucional dos tribunais de contas estaduais da Bahia e Pernambuco.” March, São Paulo.

----------- (2002) Caminhos da transparência: análise dos componentes de um sistema nacional de integridade. Campinas: Unicamp Press.

Stapenhurst, Rick (2004) The Legislature and the Budget, The World Bank Institute.

Stapenhurst, R, V Sahgal, W Woodley and R Pelizzo (2005) Scrutinizing Public Expenditures. Assessing the Performance of Public Accounts Committees, World Bank Policy Research Working Paper 3613. 
Taylor, Matthew M. and Vinicius Buranelli (2007) "Ending Up in Pizza: ccountability as a Problem of Institutional Arrangement in Brazil". Latin American Politics \& Society - V 49, N. 1, Spring , pp. 59-87

Teixeira, Marco Antônio C. (2004) Entre o técnico e o político: o Tribunal de Contas do Município de São Paulo e o controle financeiro das gestões Luiza Erundina (1989-1992) e Paulo Maluf(1993-1996). São Paulo. PhD dissertation.

Torgler, B. (2005); A Knight without a Sword? The Effects of Audit Courts on Tax Morale. Journal of Institutional and Theoretical Economics 161(4):735-60.

Torgler, B. and Chr. Schaltegger (2006); The Determinants of Political Discussion: How Important are Audit Courts and Local Autonomy? CREMA Working Paper No. 2005-28.

Uña, G., G. Cogliandro, N. Bertello and J. Labaqui (2005) El Congreso y el Presupuesto Nacional: Desempeño y Condicionantes de su Rol en el Proceso Presupuestario (Buenos Aires: Fundación Konrad Adenauer).

Voigt, S., L. Feld und A. van Aaken (2006); Power over Prosecutors Corrupts Politicians - Cross Country Evidence Using a New Indicator, Mimeo: Philipps University Marburg.

Wehner, Joachim . Back from the Sidelines? Redefining the Contribution of Legislatures the Budget Cycle. World Bank Institute

World Bank (2001); Features and functions of supreme audit institutions, Prem Notes \#59, downloaded from: ihttp://siteresources.

Zanella di Pietro, M.S. (1996). 'Coisa julgada - aplicabilidade a decisões do Tribunal de Contas da União,' Revista do Tribunal de Contas de União 27(70):23-36

Verbistky, Horacio (1993). Hacer la Corte: la construcción de un poder absoluto sinjusticia ni control. Buenos Aires: Planeta. 


\section{ANEXO 1 Transparência orçamentária e Controle Externo - América Latina e África}

\begin{tabular}{|c|c|c|c|c|c|c|c|c|c|c|c|c|c|c|}
\hline Indicador & & & & & & & & & Países & & & & & \\
\hline $\begin{array}{l}\text { Esclarecimento sobre a diferença } \\
\text { entre: }\end{array}$ & $\begin{array}{l}\text { Africa } \\
\text { Sul }\end{array}$ & Botswana & Egito & Kênea & Zâmbia & Namíbia & $\begin{array}{l}\text { Burkina } \\
\text { F. }\end{array}$ & Argelia & Tanzânia & Gâna & Angola & $\begin{array}{l}\text { Papua } \\
\text { N.G. }\end{array}$ & Nigéria & Morocos \\
\hline $\begin{array}{l}\text { Níveis aprovados e as despesas } \\
\text { realizadas }\end{array}$ & 100 & 67 & 100 & 100 & 33 & 33 & 33 & 33 & 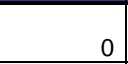 & 0 & 33 & 0 & 0 & 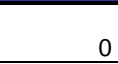 \\
\hline $\begin{array}{l}\text { Nivel de detalhamento da informação } \\
\text { item anterior }\end{array}$ & 100 & 100 & 67 & 100 & 100 & 33 & 33 & 33 & 0 & 0 & 33 & 0 & 0 & 0 \\
\hline $\begin{array}{l}\text { Níveis aprovados e as receitas } \\
\text { realizadas }\end{array}$ & 100 & 67 & 100 & 67 & 33 & 33 & 33 & 33 & 0 & 0 & 33 & 0 & 0 & 0 \\
\hline $\begin{array}{l}\text { Previsão macroeconômica e realidade } \\
\text { efetiva }\end{array}$ & 100 & 67 & 33 & 0 & 0 & 33 & 0 & 33 & 0 & 0 & 33 & 0 & 0 & 0 \\
\hline $\begin{array}{l}\text { Estimativas para dados não-financeiros } \\
\text { e resultados efetivos }\end{array}$ & 100 & 0 & 0 & 33 & 0 & 0 & 0 & 0 & 0 & 0 & 0 & 0 & 0 & 0 \\
\hline $\begin{array}{l}\text { Evolução prevista para os indicadores e } \\
\text { resultados efetivos }\end{array}$ & 100 & 0 & 0 & 0 & 33 & 0 & 0 & 0 & 0 & 0 & 0 & 0 & 0 & 0 \\
\hline $\begin{array}{l}\text { Previsão de fundos de combate à } \\
\text { pobreza e sua execução orçamentária } \\
\text { efetiva }\end{array}$ & 67 & 0 & 67 & 33 & 33 & 0 & 0 & 33 & 0 & 0 & 0 & 0 & 0 & 0 \\
\hline \multicolumn{15}{|l|}{ Divulgação: } \\
\hline $\begin{array}{l}\text { tempo discorrido para divulgação } \\
\text { execução orcamentária }\end{array}$ & 100 & 67 & 67 & 100 & 67 & 67 & 100 & 33 & 0 & 0 & 100 & 33 & 0 & 33 \\
\hline $\begin{array}{l}\text { Há auditoria dos dados da execução } \\
\text { orçamentária? }\end{array}$ & 100 & 100 & 100 & 100 & 67 & 0 & 100 & 67 & 0 & 0 & 0 & 0 & 0 & 0 \\
\hline $\begin{array}{l}\text { Execução dos fundos extra- } \\
\text { orçametários }\end{array}$ & 67 & 0 & 33 & 0 & 33 & 0 & 0 & 33 & 0 & 0 & 0 & 0 & 0 & 33 \\
\hline $\begin{array}{l}\text { tempo p realização e divulgação dos } \\
\text { resultados das auditorias }\end{array}$ & 100 & 67 & 0 & 33 & 67 & 0 & 0 & 0 & 33 & 0 & 0 & 0 & 0 & 0 \\
\hline $\begin{array}{l}\text { Percentual das despesas que são } \\
\text { auditadas após dois anos do ano- } \\
\text { exercício }\end{array}$ & 100 & 100 & 0 & 67 & 67 & 0 & 0 & 0 & 100 & 0 & 0 & 0 & 0 & 0 \\
\hline $\begin{array}{l}\text { Resumo executivo com as despesas de } \\
\text { Ministérios e Secretarías }\end{array}$ & 100 & 0 & 0 & 100 & 0 & 100 & 0 & 0 & 100 & 0 & 0 & 0 & 0 & 0 \\
\hline $\begin{array}{l}\text { Manual com recomendações das } \\
\text { auditorias }\end{array}$ & 0 & 33 & 67 & 33 & 0 & 3 & 0 & 0 & 0 & 0 & 0 & 0 & 0 & 0 \\
\hline $\begin{array}{l}\text { Medidas tomadas pelo Executivo } \\
\text { seguindo recomendações da auditoria }\end{array}$ & 67 & 67 & 0 & 67 & 0 & 0 & 0 & 0 & 0 & 0 & 0 & 0 & 0 & 0 \\
\hline \multicolumn{15}{|l|}{ Prerrogativas institucionais } \\
\hline $\begin{array}{l}\text { Consentimento p/ Legislativo ou } \\
\text { Judiciario para destituição do titular da } \\
\text { ISC }\end{array}$ & 100 & 100 & 67 & 100 & 100 & 100 & 67 & 67 & 67 & 100 & 67 & 100 & 67 & 67 \\
\hline $\begin{array}{l}\text { Há divulgação da auditoria dos fundos } \\
\text { extra-orçamentário? }\end{array}$ & 100 & 100 & 0 & 0 & 33 & 0 & 0 & 0 & 0 & 0 & 0 & 0 & 0 & 0 \\
\hline $\begin{array}{l}\text { Discricionariedade da ISC para } \\
\text { realização de auditorias }\end{array}$ & 100 & 0 & 100 & 0 & 100 & 33 & 33 & 33 & 33 & 100 & 100 & 100 & 100 & 0 \\
\hline Quem determina o orçamento da ISC & 100 & 67 & 100 & 33 & 0 & 100 & 33 & 67 & 0 & 33 & 0 & 0 & 0 & 0 \\
\hline $\begin{array}{l}\text { Análise dos relatórios de auditoria pelas } \\
\text { legislaturas }\end{array}$ & 100 & 33 & 100 & 100 & 100 & 67 & 100 & 0 & 100 & 100 & 0 & 100 & 0 & 0 \\
\hline $\begin{array}{l}\text { Acesso da legislatura a auditorias } \\
\text { realizadas sobre programas secretos }\end{array}$ & 100 & 100 & 67 & 0 & 33 & 0 & 0 & 0 & 0 & 100 & 0 & 0 & 0 & 0 \\
\hline
\end{tabular}

Fonte dos dados originais: World Bank/Open Budget Project-OECD 


\begin{tabular}{|c|c|c|c|c|c|c|c|c|c|c|c|c|}
\hline \multirow[t]{2}{*}{ Indicador } & \multicolumn{12}{|c|}{ Paises } \\
\hline & Brasil & Peru & Colômbia & México & $\begin{array}{l}\text { Costa } \\
\text { R. }\end{array}$ & Guatemala & Bolívia & Honduras & $\begin{array}{l}\text { EI } \\
\text { Salvador }\end{array}$ & Argentina & Nicarágua & Equador \\
\hline Níveis aprovados e as despesas realizadas & 100 & 100 & 67 & 67 & 67 & 33 & 100 & 67 & 33 & 33 & 33 & 0 \\
\hline $\begin{array}{l}\text { Nivel de detalhamento da informação item } \\
\text { anterior }\end{array}$ & 100 & 67 & 33 & 100 & 67 & 33 & 100 & 67 & 67 & 0 & 33 & 0 \\
\hline Níveis aprovados e as receitas realizadas & 100 & 100 & 33 & 67 & 67 & 33 & 100 & 67 & 67 & 33 & 33 & 0 \\
\hline Previsão macroeconômica e realidade efetiva & 100 & 100 & 33 & 33 & 0 & 0 & 0 & 33 & 0 & 0 & 0 & 0 \\
\hline $\begin{array}{l}\text { Estimativas para dados não-financeiros e } \\
\text { resultados efetivos }\end{array}$ & 67 & 33 & 0 & 33 & 33 & 0 & 0 & 0 & 0 & 33 & 0 & 0 \\
\hline $\begin{array}{l}\text { Evolução prevista para os indicadores e } \\
\text { resultados efetivos }\end{array}$ & 33 & 67 & 0 & 33 & 67 & 0 & 0 & 0 & 0 & 0 & 0 & 0 \\
\hline $\begin{array}{l}\text { Previsão de fundos de combate à pobreza e sua } \\
\text { execução orçamentária efetiva }\end{array}$ & 100 & 67 & 33 & 67 & 0 & 0 & 0 & 67 & 0 & 0 & 0 & 0 \\
\hline \multicolumn{13}{|l|}{ Divulgação: } \\
\hline $\begin{array}{l}\text { tempo discorrido para divulgação execução } \\
\text { orcamentária }\end{array}$ & 100 & 67 & 100 & 100 & 100 & 100 & 100 & 100 & 100 & 100 & 100 & 67 \\
\hline $\begin{array}{l}\text { Há auditoria dos dados da execução } \\
\text { orçamentária? }\end{array}$ & 100 & 100 & 33 & 33 & 100 & 0 & 0 & 0 & 0 & 33 & 0 & 0 \\
\hline Execução dos fundos extra-orçametários & 33 & 33 & 33 & 67 & 0 & 33 & 0 & 0 & 33 & 33 & 0 & 0 \\
\hline $\begin{array}{l}\text { tempo p realização e divulgação dos resultados } \\
\text { das auditorias }\end{array}$ & 100 & 67 & 100 & 33 & 100 & 100 & 0 & 33 & 0 & 0 & 0 & 0 \\
\hline $\begin{array}{l}\text { Percentual das despesas que são auditadas após } \\
\text { dois anos do ano-exercício }\end{array}$ & 67 & 100 & 67 & 33 & 33 & 67 & 0 & 33 & 0 & 0 & 0 & 0 \\
\hline $\begin{array}{l}\text { Resumo executivo com as despesas de } \\
\text { Ministérios e Secretarías }\end{array}$ & 33 & 0 & 100 & 100 & 67 & 100 & 100 & 0 & 0 & 0 & 0 & 0 \\
\hline Manual com recomendações das auditorias & 0 & 33 & 33 & 33 & 33 & 0 & 0 & 0 & 0 & 0 & 0 & 0 \\
\hline $\begin{array}{l}\text { Medidas tomadas pelo Executivo seguindo } \\
\text { recomendações da auditoria }\end{array}$ & 67 & 0 & 67 & 67 & 0 & 0 & 33 & 0 & 0 & 0 & 0 & 0 \\
\hline \multicolumn{13}{|l|}{ Prerrogativas institucionais } \\
\hline $\begin{array}{l}\text { Consentimento p/ Legislativo ou Judiciario para } \\
\text { destituição do titular da ISC }\end{array}$ & 100 & 100 & 100 & 100 & 100 & 100 & 100 & 100 & 100 & 100 & 100 & 100 \\
\hline $\begin{array}{l}\text { Há divulgação da auditoria dos fundos extra- } \\
\text { orçamentário? }\end{array}$ & 67 & 100 & 67 & 100 & 0 & 33 & 0 & 0 & 0 & 0 & 0 & 0 \\
\hline $\begin{array}{l}\text { Discricionariedade da ISC para realização de } \\
\text { auditorias }\end{array}$ & 100 & 67 & 100 & 67 & 100 & 100 & 100 & 100 & 100 & 67 & 100 & 100 \\
\hline Quem determina o orçamento da ISC & 33 & 33 & 100 & 33 & 100 & 33 & 67 & 33 & 100 & 100 & 33 & $\underline{0}$ \\
\hline $\begin{array}{l}\text { Análise dos relatórios de auditoria pelas } \\
\text { legislaturas }\end{array}$ & 100 & 67 & 100 & 67 & 67 & 100 & 33 & 33 & 33 & 0 & 33 & 0 \\
\hline $\begin{array}{l}\text { Acesso da legislatura a auditorias realizadas } \\
\text { sobre programas secretos }\end{array}$ & 0 & 67 & 67 & 0 & ni & 0 & 0 & 33 & 0 & 0 & 0 & 0 \\
\hline
\end{tabular}

Fonte dos dados originais: World Bank/Open Budget Project-OECD 
This document was created with Win2PDF available at http://www.win2pdf.com.

The unregistered version of Win2PDF is for evaluation or non-commercial use only. 